\title{
L-asparaginase: therapeutic use and applications in the food industry - a review
}

\author{
L-asparaginase: uso terapêutico e aplicações na indústria de alimentos - uma revisão \\ L-asparaginasa: uso terapéutico y aplicaciones en la industria alimentaria - una revisión
}

Received: 08/02/2021 | Reviewed: 08/08/2021 | Accept: 08/17/2021 | Published: 08/21/2021

\author{
Maycon Douglas de Oliveira \\ ORCID: https://orcid.org/0000-0001-6736-4384 \\ Universidade Federal de Uberlândia, Brazil \\ E-mail: maycon.oliveira@ufu.br \\ Carlos Johnantan Tolentino Vaz \\ ORCID: https://orcid.org/0000-0002-8706-0334 \\ Universidade Federal de Uberlândia, Brazil \\ E-mail: escritorio@ showengenharia.com.br \\ Liliane Maciel de Oliveira \\ ORCID: https://orcid.org/0000-0001-7142-3631 \\ Universidade Federal de Uberlândia, Brazil \\ E-mail: liliane_mo@ufu.br \\ Carla Zanella Guidini \\ ORCID: https://orcid.org/0000-0002-6562-8160 \\ Universidade Federal de Uberlândia, Brazil \\ E-mail: carlazguidini@ufu.br
}

\begin{abstract}
L-asparaginase (L-asnase) is an amino hydrolase that has been used in the last decades for leukemia treatment, which boosted scientific studies on production, purification and immobilization of this enzyme. More recently, L-asnase has called food industry attention because of its effect on acrylamide formation in fried and baked foods. Several studies have been carried out in order to evaluate the effect of L-asnase in reducing acrylamide formation in different food models. This review brings up an overview in L-asnase kinetic parameters from different sources, immobilization methods, its therapeutic use in leukemia treatment and food processing applications. This review also discusses acrylamide formation in fried and baked foods. Commercial L-asnase is produced by two microorganisms, Escherichia coli and Erwinia sp. However, studies using different microorganisms have shown the possibility of producing this enzyme from different sources, obtaining enzymes with interesting kinetic properties. Immobilization strategies have provided enzymes with greater activity and stability, which could contribute to maintain L-asnase activity in the body for longer periods. Researches applying L-asnase in food products have shown significant reduction in acrylamide production, above $90 \%$ in some cases. For this purpose, during enzyme application some variables must be taken into account, as enzyme dose, food matrix, pretreatment, processing time and temperature. Medical and food applications make L-asnase a multipurpose enzyme. Reducing prices, improving enzyme stability and reducing co-lateral effects in leukemia treatment are still challenges to overcome.
\end{abstract}

Keywords: Enzyme; L-asparaginase; Acrylamide; Immobilization; Food; Leukemia treatment.

\section{Resumo}

L-asparaginase (L-asnase) é uma hidrolase amino que tem sido usada nas últimas décadas para o tratamento da leucemia, o que impulsionou estudos científicos sobre produção, purificação e imobilização dessa enzima. Mais recentemente, a L-asnase chamou a atenção da indústria alimentícia por causa de seu efeito na formação de acrilamida em alimentos fritos e cozidos. Vários estudos têm sido realizados para avaliar o efeito da L-asnase na redução da formação de acrilamida em diferentes modelos alimentares. Esta revisão traz de uma visão geral da cinética de Lasnases obtidas de diferentes fontes, métodos de imobilização, seu uso terapêutico no tratamento de leucemia e processamento de alimentos. Esta revisão também discute a formação de acrilamida em alimentos fritos e cozidos. A Lasnase comercial é produzido por dois microrganismos, Escherichia coli e Erwinia sp. No entanto, estudos utilizando diferentes microrganismos têm mostrado a possibilidade de produzir essa enzima de diferentes fontes, obtendo enzimas com propriedades cinéticas interessantes. Estratégias de técnicas de imobilização através de sistemas nano ou microparticulado têm proporcionado enzimas com maior atividade e estabilidade, o que poderia contribuir para manter a atividade L-asnase no corpo por períodos mais longos. Pesquisas que aplicam L-asnase em produtos alimentícios têm mostrado redução significativa na produção de acrilamida, acima de $90 \%$ em alguns casos. Para isso, durante a aplicação da enzima, algumas variáveis devem ser levadas em consideração, como dose enzimática, matriz alimentar, pré-tratamento, tempo de processamento e temperatura. Aplicações médicas e alimentares fazem da L-asnase uma 
enzima multiuso. Reduzir os preços, melhorar a estabilidade das enzimas e reduzir os efeitos co-laterais no tratamento da leucemia ainda são desafios a serem superados.

Palavras-chave: Enzima; L-asparaginase; Acrilamida; Imobilização; Alimentos; Tratamento da leucemia.

\section{Resumen}

La L-asparaginasa (L-asnasa) es una amino hidrolasa que se ha utilizado en las últimas décadas para el tratamiento de la leucemia, lo que ha estimulado estudios científicos sobre la producción, purificación e inmovilización de esta enzima. Más recientemente, la L-asnasa ha llamado la atención de la industria alimentaria debido a su efecto sobre la formación de acrilamida en alimentos fritos y cocinados. Se han realizado varios estudios para evaluar el efecto de la L-asnasa en la reducción de la formación de acrilamida en diferentes modelos dietéticos. Esta revisión de literatura trae una descripción general de la cinética de l-asnasas obtenidas por diferentes fuentes, métodos de la inmovilización, su uso terapéutico en el tratamiento de la leucemia y en el proceso de alimentos. Esta revisión también analiza la formación de acrilamida en alimentos fritos y cocinados. La L-asnasa comercial es producida por dos microorganismos, Escherichia coli y Erwinia sp. Sin embargo, estudios utilizando diferentes microorganismos han demostrado la posibilidad de producir esta enzima a partir de diferentes fuentes, obteniendo enzimas con interesantes propiedades cinéticas. Las estrategias de técnicas de inmovilización a través de nano y microsistemas han proporcionado a las enzimas una mayor actividad y estabilidad, lo que podría contribuir a mantener la actividad de la asnasa en el organismo durante períodos más largos. La investigación que aplica L-asnasa a productos alimenticios ha mostrado una reducción significativa en la producción de acrilamida, por encima del $90 \%$ en algunos casos. Para ello, durante la aplicación de la enzima, se deben tener en cuenta algunas variables, como la dosis enzimática, la matriz alimentaria, el pretratamiento, el tiempo de procesamiento y la temperatura. Las aplicaciones médicas y alimentarias hacen de la L-asnasa una enzima multipropósita. La reducción de los precios, la mejora de la estabilidad de las enzimas y la reducción de los efectos secundarios en el tratamiento de la leucemia siguen siendo retos por superar.

Palabras clave: L-asparaginasa; Acrilamida; Inmovilización; Alimentación; Tratamiento de leucemia.

\section{Introduction}

Special enzymes require greater purification and specificity, as they are targeted for therapeutic, diagnostic, analytical and research use. A wide range of enzymes, from different sources and for different therapeutic and diagnostic use is available on the market (Rigon Zimmer et al., 2009; Kunamneni, Ogaugwu, \& Goli, 2018).

Therapeutic use of enzymes dates back to the end of the 19th century, when crude preparations of porcine pancreatic enzymes were used as digestive aids (Cruz et al., 2008). Since then, industries have been developing a wide variety of enzymebased medications for clinical use, such as antiseptics, anti-inflammatories, reconstituting of hemostatic and other metabolic enzymes, digestive aids, inhibitors of coagulation in the treatment of cystic fibrosis, as well as cancer drugs. Therapeutic enzymes are generally available as lyophilized preparations containing biocompatible buffering salts and mannitol diluent. According to treatment purpose, enzymes can be administered topically, orally, intravaginally and parenterally (Rigon Zimmer et al., 2009; Kunamneni, Ogaugwu, \& Goli, 2018).

Among the main therapeutic enzymes of microbial origin, L-asparaginase stands out. It is an important chemotherapeutic agent used in the treatment of a variety of lymphoproliferative disorders and lymphomas, in particular, acute lymphoblastic leukemia (ALL). The use of L-asparaginase has been a cornerstone of combined chemotherapy protocols used in the treatment of pediatric ALL for almost 30 years. Blast cells need asparagine to survive but they do not have the enzyme asparagine synthase. As L-asparaginase is able to deplete plasmatic asparagine, it causes death of blast cells (Narta, Kanwar \& Azmi, 2007).

In addition to their therapeutic use, the field of applications of L-asparaginases has been expanding. For instance, they are used by the food industry to reduce the formation of acrylamide in starch rich foods (Sanghvi et al., 2016). Acrylamide is a low molecular weight hydrophilic compound formed in heat-treated food products. Its formation occurs during cooking or frying of carbohydrates and asparagines rich foods at temperatures above $120{ }^{\circ} \mathrm{C}$. Acrylamide is mainly formed from the reduction of sugars and asparagine in the Maillard reaction. This compound was considered "potentially carcinogenic to humans" by the International Cancer Research Agency (Mottram, Wedzicha \& Dodson 2002; Liu, 2018; IARC, 2014). L- 
asparaginase is an enzyme that catalyzes hydrolysis of asparagine in aspartic acid and ammonia, and is therefore used in the supply of some food products to reduce acrylamide content (Pedreschi, Kaack \& Granby, 2008).

In most cases, biocatalysts are relatively expensive due to the several steps involved in their production, such as fermentation, extraction, purification and stabilization. Therefore, enzyme recovery and reuse are interesting strategies to reduce industry costs in the acquisition of enzymes. Enzymatic immobilization is another attractive strategy, as it provides easy recovery of enzymes, allows reactor design simplification, provides simpler reaction control, limits use of toxic or highly reactive reagents, and makes processes simpler and more robust. It is the simplest solution to the solubility problem of biocatalysts. Thus, immobilization is generally applied to enzymes used in industrial applications (Labrou \& Muharram, 2016).

Enzyme immobilization using nanoparticulate systems has been another promising approach due to its unique properties, such as small size, in addition to the correspondence between a large specific surface area, making it a suitable technique for therapeutic enzyme immobilization (Baskar et al., 2015). In order to face the aforementioned challenges, the immobilization of enzymes in nanoparticles, or versatile carriers in support matrices for immobilization purposes, have exceptional properties such as high mass transfer, ease of separation and recovery due to their adherence to the support, in addition to representing a Remarkable green chemistry approach as it extends biocatalyst life through multiple recovery cycles (Bilal et al., 2018). However, the entrapment of enzymes in support materials can result in several enzymatic modifications, as changes in the structure and activity of the enzyme must be studied and evaluated according to the target application (Clark, 1994).

Therefore, L-asparaginase is an enzyme with important applications in medical and food fields. In this review, studies about the kinetic of free and immobilized L-asparaginase, produced by different microorganisms, and studies that investigated the use of this enzyme to reduce acrylamide in food and to treat leukemia were compiled and discussed.

\section{Methodology}

The literature review was carried out according to the methodology proposed by Souza et al. (2017) and Moher et al. (2009), with some modifications. The bibliographic research was performed in the databases Web of Science, Science Direct, SciELO, PubMed and Scopus, using keywords related to L-asparaginase production, immobilization and encapsulation; 1asparaginase kinetic; acrylamide in foods; l-asparaginase applications in leukemia treatment and in reduction of acrylamide in food. Molecular studies of L-asparaginase and publications involving its production, purification, immobilization and application that did not provide quantitative data on enzyme production and enzymatic activity, studies that showed the use of other enzymes in the reduction of acrylamide, and studies that did not completely purify the enzyme or did not characterize the kinetic of the purified enzyme were discarded.

\section{Literature Review and Discussion}

\subsection{L - asparaginase}

L-asparaginase, also known as aminohydrolase, belongs to the group of enzymes amidase (Kumar \& Verma, 2012). Normally, L-asparaginase exists as a tetramer, but it is also found in hexameric, dimeric or monomeric form. Different forms are obtained when the enzyme is isolated from different sources. Most bacterial L-asparaginases exhibit quaternary or tertiary structures (Ln et al., 2011). and the tetramer consists of four identical subunits. Altogether, the molecule has two intimate dimers within its molecular structure where non-allosteric catalytic centers are created. Every active site is modeled by the transport of amino acids in two adjacent monomers. The amino acids that constitute the active site are Thr15, Tyr29, Ser62, 
Glu63, Thr95, Asp 96, Ala120 and Lys168, with the amino acids Thr15 and Thr95 being the residues responsible for catalytic activity of the enzyme (Jaskólski et al., 2001).

Asparaginase is the enzyme responsible for irreversible hydrolytic catalysis of L-asparagine in L-aspartic acid and ammonium; it is found in certain plants, animals and microorganisms but never in humans. The amino acid L-asparagine comes from human diet, but it is also synthesized by the enzyme L-asparagine synthetase from L-aspartic acid, L-glutamine and Adenosine Triphosphate - ATP (Verma et al., 2007).

L-asparaginase enzymes can be classified based on amino acids sequence, biochemical characteristics of the enzyme, group of origin (bacterial, vegetable and rhizobial), or enzymatic type (type I and type II asparaginase). Type I and type II enzymes are characterized by their enzymatic activity on L-,asparagine and L-glutamine (Izadpanah et al., 2018). Type I asparaginases are found in the cytosol, and are called cytosolic asparaginase. They show low affinity for L-asparagine and a greater affinity for L-glutamine. Type II asparaginases are found in the vicinity of periplasmic spaces and are produced extracellularly, showing high affinity for L-asparagine and being less specific to L-glutamine (Hendriksen et al., 2009). Hence, type II enzyme exhibits higher specific action against L-asparagine. Enzyme's activity also varies with strain and fermentation conditions.

Asparaginase type II shows precisely greater antitumor activity than type I and is used as a chemotherapeutic agent. It has also been better studied and applied in the food industry to remove asparagine from primary ingredients, before food processing, in order to reduce formation of acrylamide (Kotzia \& Labrou, 2007; Hendriksen et al., 2009).

Type II L-asparaginases, produced by mesophilic microorganisms, are tetramers of identical subunits with molecular masses in the range 140-160 kDa, while type I L-asparaginases, produced by thermophiles, are homodimers with molecular masses around $70 \mathrm{kDa}$. Both types of L-aspariganase can be obtained from the same source, such as Escherichia coli, which produces these two isoenzymes or synthesized by other microbial sources (Pourhossein \& Korbekandi, 2014; Shi et al., 2017). In clinical applications, high molecular weight biocatalysts can cause some serious deeds. Type II L-asparaginase can lead to problems such as liver and pancreas dysfunction, central nervous system toxicity, edema, skin rashes, fever, diabetes, leukopenia, hemorrhage and others (Ramya et al., 2012; Batool et al., 2016).

\subsubsection{L - asparaginase - Enzyme for therapeutic use}

Differently from the industrial use of enzymes, therapeutic enzymes are needed in relatively small amounts but generally with a high degree of purity and specificity. The kinetics of these enzymes must be high to assure an efficient enzymatic process, even at low enzyme and substrate concentrations (Gurung et al., 2013).

L-asparaginase belongs to the group of therapeutic enzymes with antineoplastic properties that has been extensively studied by researchers and scientists. It was first observed by Lang and Uber. Research studies regarding the use of Lasparaginase as medicine started when Kidd (1953) carried out his studies using serum of guinea pigs (Cavia porcellus) and mice with subcutaneous lymphomas. He injected the serum into the intraperitoneal region of sick mice and observed that the injection was capable of causing regression in tumor growth. Soon after, Neuman and Mccoy in 1956 verified the metabolic need of "Walker carcinosarcoma 256" cancer cells in the supply of the amino acids L-asparagine and L-glutamine. After several studies, as previously reported, Mashburn \& Wriston (1963) found that the antitumor activity of guinea pig serum was due to the enzyme L-asparaginase from that serum. Furthermore, studies carried out by Mashburn \& Wriston (1963) verified the potential of microbial asparaginase enzyme as a chemotherapeutic agent, which inhibits tumor growth. This research found that tumor cells require asparagine as a source of nutrients, and that L-asparaginase could be a method capable of depleting the amino acid asparagine through hydrolysis. Thus, L-asparaginase would indirectly inhibit or slow down the growth of 
malignant tumors and lymphoblastic lymphomas by reducing plasma concentration of asparagine in the body (Bakshi \& Patel, 2019; Batool et al., 2016). Currently, L-asparaginase is used as a drug to treat certain hematopoietic tumors, being able to reduce plasma levels of L-asparagine in patients (Pieters et al., 2011).

Lymphoblasts need large amounts of the amino acid L-asparagine to maintain their rapid and malignant growth, but they are unable to synthesize it. Neoplastic cells do not have the ability to synthesize asparagine due to the absence of Lasparagine synthetase. Therefore, they depend on the exogenous supply of asparagine for survival and growth. The use of Lasparaginase as clinical treatment causes the circulating asparagine to be drastically reduced, which leads to the starvation of cancer cells. The absence of asparagine causes inhibition in protein biosynthesis, and cells undergo apoptosis. Thereby, tumor growth is significantly controlled (Batool et al., 2016).

Healthy cells, on the other hand, have the enzyme L-asparagine synthase, which converts L-aspartic acid into Lasparagine, being slightly affected by treatment with L-asparaginase (Pieters et al., 2011). Normal cells synthesize Lasparagine using the enzyme transaminase, which performs the conversion of oxaloacetate into an intermediate aspartate. After this, the transfer of an amino group from glutamate to oxaloacetate occurs producing $\alpha$-ketoglutarate and aspartate molecules. Asparagine is synthesized from aspartate and the amino group comes from glutamine (Batool et al., 2016). The effect of 1asparaginase on 1-asparagine depletion and on lymphoblasts and healthy cells are represented in Figure 1.

It should be noted, however, that there are tumor cells that also have the L-asparagine synthase enzyme and are resistant to treatment with L-asparaginase, since they convert L-aspartic acid into L-asparagine and do not suffer from the absence of this amino acid (Van Den Berg, 2011; Verma et al., 2007; Pieters et al., 2011). The use of L-asparaginase as a drug is currently only standardized for the treatment of pediatric patients with acute lymphoblastic leukemia (ALL) and for some types of lymphomas, since tumor cells from these leukemias are the most susceptible to treatment with this enzyme (Pieters et al., 2011).

Figure 1 - Effect of L-asparaginase on 1-asparagine depletion, and on healthy and acute lymphoblastic leukemia cells.

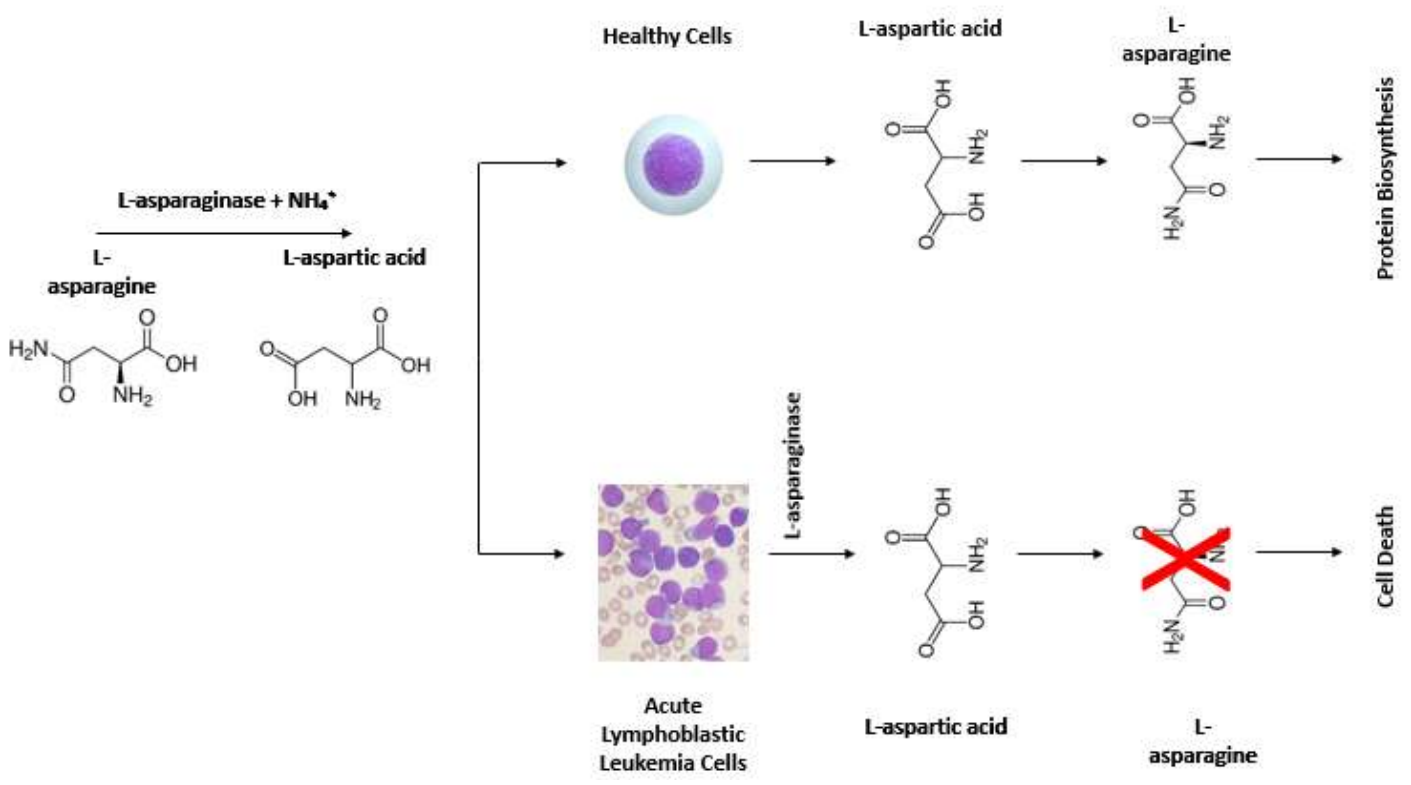

Source: Adapted from Mottram et al. (2002).

\subsubsection{L - asparaginase - Enzyme for food use}

The search for high quality food in terms of food technology coupled with food security in developing countries has 
created a shift towards innovation and production of new foods. This demand triggered the need for transformation within the food industry (Li et al., 2012).

Within this context, the enzyme L'asparaginase of microbial origin gained prominence (Krishnapura \& Belur, 2016; Krishnapura, Belur \& Subramanya, 2016; Mohan Kumar et al., 2014). In recent years, L-asparaginase has been used as a food enzyme due to its application in reducing the formation of acrylamide. Asparagine is present in most starchy foods. This amino acid reacts with reducing sugars during thermal processing, leading to the formation of an undesirable compound called acrylamide, which is one by-product of the Maillard reaction (Mottram, Wedzicha \& Dodson 2002). Acrylamide molecular structure is illustrated in Figure 2.

Figure 2 - Chemical structure of acrylamide.

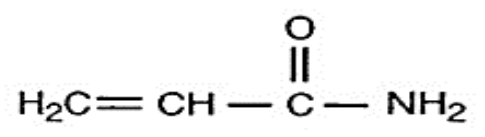

Source: Authors.

In 1994, acrylamide was classified as "potentially carcinogenic to humans" by the International Agency for Research on Cancer - IARC (2014). In 2001, the European Committee on Toxicity, Ecotoxicity and Environment demonstrated its toxic effects in animals, such as neurotoxicity, genotoxicity, carcinogenesis and reproductive toxicity. According to Claus, Carle \& Schieber (2008), the results of a study with several rodent models showed that acrylamide produces tumorigenesis in multiple hormonally regulated organs, such as the mammary gland, thyroid and peritesticular mesothelium. Therefore, it is a potent carcinogen and neurotoxic compound that forms an adduct with hemoglobin when consumed in high doses, and causes reproductive disability (Tyl \& Friedman, 2003).

Figure 3 - Mechanism of acrylamide formation in foods processed under high temperatures.

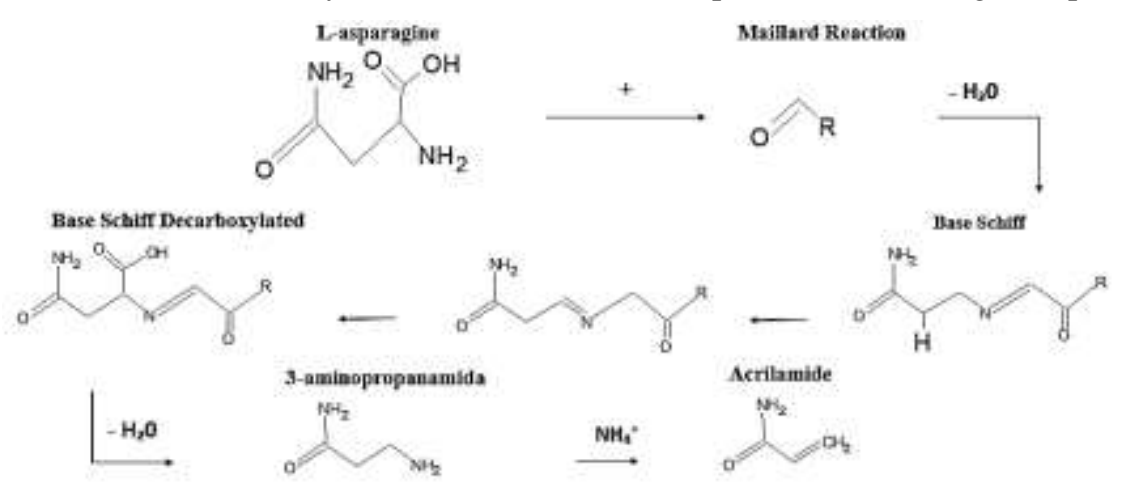

Source: Adapted from Granvogl and Schieberle (2006) and Mustafa (2008)

The main steps of acrylamide formation are shown in Figure 3. The first reaction occurs between the free asparagine with a carbonyl source (amino-carbonyl reaction), resulting in the compound $\mathrm{N}$-glycosylated asparagine, which undergoes dehydration at high temperature to give rise to the Schiff base (imine). The Schiff base undergoes additional decarboxylation and, after tautomerization, the decarboxylated Amadori compound is formed. Subsequently, this compound reacts by breaking the carbon-nitrogen covalent bond resulting in the formation of acrylamide, together with an amino ketone. In another reaction route, the decarboxylated Schiff base is decarboxylized again to form a new compound, 3-aminopropionamide (3-APA), which 
in turn, forms acrylamide with the removal of ammonia (Granvogl \& Schieberle, 2006). The decarboxylation of free asparagine at high temperatures $\left(100-180{ }^{\circ} \mathrm{C}\right)$ forms the compound 3-aminopropionamide, which gives rise to acrylamide in later steps. Therefore, the presence of reducing sugars is not always necessary for the production of acrylamide (Mustafa, 2008).

Some agronomic characteristics and processing strategies directly affect the formation and degradation of acrylamide in foods (Elmore et al., 2005). Selection of food varieties with low reducing sugar content, storage under controlled conditions, immersion and bleaching, addition of sodium diphosphate, reduced frying temperature, control of final moisture content, among others strategies have contributed to reduce acrylamide formation (Mesías \& Morales, 2016; Sanny et al., 2013). Variable and process parameters that must be controlled because of their effect during the reaction of acrylamide formation can be classified into four groups. Group A variables are related to food chemical composition: reducing sugar content, total sugar content, asparagine content, color, and humidity parameters. Group B variables are related to frying process, such as type of frying oil, content of polar compounds in the frying oil, use of immersion or not, and type of equipment. In group C there are variables that involve roasting of food, during which temperature and humidity directly influence acrylamide formation. And finally, group D variables include food-related properties, such as color and thickness parameters. According to studies carried out with food models, all of these parameters directly interfere on the formation of acrylamide (Mesías \& Morales, 2016).

Continued efforts to understand the pathway of acrylamide formation have demonstrated that other carbonyls besides $\alpha$-hydroxycabonyl can react with asparagine to produce acrylamide. Only one carbonyl compound is needed to convert asparagine to acrylamide, and carbonyl can come from several sources. One example is the reaction with sucrose that produces 5-hydroxymethylfurfural (5-(hydroxymethyl) furan-2-carbaldehyde) (HMF), a furan compound that is formed by direct dehydration of sugars in acidic conditions (caramelization) and is also an intermediate in Maillard reaction (Jin, Wu, \& Zhang, 2013). HMF contains $\alpha, \beta, \gamma, \delta$-di-unsaturated carbonyl groups that can efficiently convert free asparagine to acrylamide during heating (Zamora \& Hidalgo, 2008). As mentioned above, intermediates in the Maillard reaction can be a source of reactive carbonyls that, when heated with asparagine, form a series of intermediates such as specific flavonoids that lead to the formation of acrylamide. Nonetheless, there are also lipid oxidation reactions that contribute to the formation of acrylamide. It has been demonstrated that lipid oxidation products are capable of converting asparagine to acrylamide. This conversion is favored by oxidized lipids with an $\alpha, \beta, \gamma, \delta$-di-unsaturated carbonyl group, which comes from the oxidation of unsaturated fatty acids and their corresponding esters (Zamora \& Hidalgo, 2008). Other reaction pathways can also contribute to the formation of the acrylamide compound, such reaction pathways not involving asparagine that will not be discussed in this review. This approach is considered efficient because asparagine is not a major contributor to taste and color of cooked foods, so desirable sensory properties are maintained (Parker et al., 2012).

Several studies have been carried out regarding reduction of acrylamide formation in foods, which made it possible to establish guidelines for the thermal processing of food. Study demonstrated that enzymatic pretreatment of foods with the enzyme asparaginase leads to significant reduction of acrylamide content, in addition to other treatment procedures (Agarwal \& Sahu, 2014; Panel \& Chain, 2015; Meghavarnam \& Janakiraman, 2018). Different food products have been subjected to pretreatment with asparaginase, clearly demonstrating a reduction of acrylamide (Ravi \& Gurunathan, 2018; Anese, 2016).

\subsection{Sources of L-asparaginase}

The presence of L-asparaginase has been reported in several organisms, including animals, plants and microorganisms, except humans. Although it is present in several groups of animals and plants, other sources such as microorganisms (bacteria, fungi, algae, yeasts and actinomycetes) are considered more appropriate for use due to the 
Research, Society and Development, v. 10, n. 10, e596101018980, 2021

complexity of extraction procedures (Batool et al., 2016).

Enzymatic preparations obtained from plant extracts or animal tissue have been commonly used, although microorganisms are by far the main suppliers of commercial enzymes for food applications. They are easier to cultivate and manipulate than mammalian or vegetable cells, which allows large-scale production. In addition, they are considered reliable sources due to selectivity in biosynthesis. Microorganism producers of commercial enzymes are specifically selected or genetically modified in order to maximize enzyme production and reduce contaminants. Enzymes of animal origin bring a considerable risk both in handling and in manufacturing such as contamination by disease, which is much more complex to handle and expensive than microbial production (Agarwal \& Sahu, 2014).

Studies on asparaginase production from different microorganisms are presented in Table 1, including fungi, yeast and bacteria. It can be observed that kinetic parameters, optimum $\mathrm{pH}$ and temperature, and enzyme stability differ among the enzyme source. During selection of an enzyme for practical purposes, an important parameter to take into account is the Km value (Michaelis-Menten constant), that indicates the enzyme affinity to the substrate. Lower Km values indicates higher affinity (El-Naggar et al., 2016; Desai \& Hungund, 2018). L-asparaginase produced by Trichoderma viride exhibited the lowest $\mathrm{Km}$ among the studies mentioned in Table 1 . Another advantage of this enzyme is its stability. It preserved $92 \%$ of its initial activity after $24 \mathrm{~h}$ incubated at $37^{\circ} \mathrm{C}$. It's optimum $\mathrm{pH}$ and temperature corresponds to the physiological $\mathrm{pH}$ and body temperature, making it a suitable option for further studies in leukemia treatment (Lincoln, Niyonzima \& More, 2019). Acrylamide reduction in potato was observed for 1-asparaginase produced by Trichoderma viride, B. subtilis KDPS1 and Thermococcus zilligii AN1 TziAN1_1 (Zuo et al., 2015; Sanghvi et al., 2016; Lincoln, Niyonzima \& More, 2019). For food processing applications, different enzymes with different optimum $\mathrm{pH}$ and temperature are required, as the food $\mathrm{pH}$ and the processing temperature may vary. Citotoxic and/or anticancer activities against different cancer cell lines were observed for Lasparaginase produced by Aspergillus niger AKV-MKBU, Bacillus tequilensis PV9W, Pseudomonas otitidis, Aspergillus oryzae CCT 3940, Nocardiopsis alba NIOT-VKMA08, Streptomyces fradiae NEAE-82 (Meena et al., 2015; Dias et al., 2016; El-Naggar et al., 2016; Shakambari et al., 2016; Husain et al., 2016b; Vala et al., 2018). 
Research, Society and Development, v. 10, n. 10, e596101018980, 2021

(CC BY 4.0) | ISSN 2525-3409 | DOI: http://dx.doi.org/10.33448/rsd-v10i10.18980

Table 1 - L-asparaginase from microbial sources: kinetic parameters, optimal pH and temperature, operational stability, and applications

\begin{tabular}{|c|c|c|c|c|c|c|c|c|}
\hline $\begin{array}{l}\text { Source } \\
\text { Microorganism }\end{array}$ & $\begin{array}{l}\text { Production } \\
\text { Methods * }\end{array}$ & $\begin{array}{l}\text { Optimum } \\
\text { pH }\end{array}$ & $\begin{array}{c}\text { Optimum } \\
\text { Temperature } \\
\left({ }^{\circ} \mathrm{C}\right) \\
\end{array}$ & $\operatorname{Vmax} * *$ & $\mathbf{K} \mathbf{m} * *$ & Operation Stability & Applications & References \\
\hline \multicolumn{9}{|c|}{ Bacteria, Fungi and yeasts } \\
\hline $\begin{array}{l}\text { Trichoderma } \\
\text { viride }\end{array}$ & $\mathrm{SmF}$ & 7 & 37 & $270.27 \mathrm{U} / \mathrm{mL}$ & $\begin{array}{c}2.56 \times 10^{-3} \\
\mathrm{mM}\end{array}$ & $92 \%\left(37^{\circ} \mathrm{C}, 24 \mathrm{~h}\right)$ & $\begin{array}{l}\text { Reduced acrylamide } \\
\text { level in potato }\end{array}$ & $\begin{array}{c}\text { (Lincoln, } \\
\text { Niyonzima \& } \\
\text { More, 2019) }\end{array}$ \\
\hline $\begin{array}{l}\text { A. niger } A K V \text { - } \\
M K B U\end{array}$ & $\mathrm{SmF}$ & 7 & 30 & $\begin{array}{c}6.228 \\
\mu \mathrm{mol} / \mathrm{mg} / \mathrm{min}\end{array}$ & $0.814 \mathrm{mM}$ & $\begin{array}{c}\sim 100 \%\left(\mathrm{pH} 7,4^{\circ} \mathrm{C}, 24 \mathrm{~h}\right) \\
\sim 100 \%\left(20^{\circ} \mathrm{C}, 1 \mathrm{~h}\right)\end{array}$ & $\begin{array}{c}\text { Activity against } \\
\text { several cancer cell } \\
\text { lines }\end{array}$ & (Vala et al., 2018) \\
\hline $\begin{array}{l}\text { B. subtilis } \\
\text { WB600 }\end{array}$ & $\mathrm{SmF}$ & - & 65 at $\mathrm{pH} 7.5$ & - & $5.29 \mathrm{mM}$ & $>50 \%\left(65^{\circ} \mathrm{C}, \mathrm{pH} 7,5,61 \mathrm{~min}\right)$ & - & (Feng et al., 2017) \\
\hline $\begin{array}{l}\text { B. subtilis } \\
\text { KDPS1 }\end{array}$ & SSF & 5 & 37 & - & - & $>80 \%\left(\mathrm{pH} 5,37^{\circ} \mathrm{C}, 8 \mathrm{~h}\right)$ & $\begin{array}{l}\text { Reduction of } \\
\text { acrylamide formation } \\
\text { in fried potatoes }\end{array}$ & $\begin{array}{l}\text { (Sanghvi et al., } \\
\text { 2016) }\end{array}$ \\
\hline $\begin{array}{l}\text { B. tequilensis } \\
P V 9 W\end{array}$ & $\mathrm{SmF}$ & 8.5 & 35 & $\begin{array}{c}7.46 \\
\mu \mathrm{mol} / \mathrm{ml} / \mathrm{min}\end{array}$ & $0.045 \mathrm{mM}$ & - & $\begin{array}{l}\text { Citotoxic activity } \\
\text { against human } \\
\text { cervical cancer cells }\end{array}$ & $\begin{array}{c}\text { (Shakambari et al., } \\
\text { 2016) }\end{array}$ \\
\hline $\begin{array}{l}\text { Enterobacter } \\
\text { cloacae }\end{array}$ & $\mathrm{SmF}$ & $7-8$ & $35-40$ & $2.22 \mathrm{IU} / \mu \mathrm{g}$ & $1.58 \mathrm{mM}$ & - & - & $\begin{array}{l}\text { (Husain et al., } \\
\text { 2016a) }\end{array}$ \\
\hline $\begin{array}{l}\text { Pseudomonas } \\
\text { otitidis }\end{array}$ & $\mathrm{SmF}$ & 7.5 & 40 & - & - & - & $\begin{array}{l}\text { Anticancer activity } \\
\text { comparable or higher } \\
\text { to commercial } \\
\text { asparaginase }\end{array}$ & $\begin{array}{l}\text { (Husain et al., } \\
\text { 2016b) }\end{array}$ \\
\hline
\end{tabular}


Table 1 (continued): L-asparaginase from microbial sources: kinetic parameters, optimal $\mathrm{pH}$ and temperature, operational stability, and applications

\begin{tabular}{|c|c|c|c|c|c|c|c|c|}
\hline $\begin{array}{l}\text { Source } \\
\text { Microorganism }\end{array}$ & $\begin{array}{l}\text { Production } \\
\text { Methods }\end{array}$ & pH & $\begin{array}{l}\text { Temperature } \\
\left({ }^{\circ} \mathrm{C}\right)\end{array}$ & Vmax & $\mathbf{K m}$ & Operation Stability & Applications & References \\
\hline \multicolumn{9}{|c|}{ Bacteria, Fungi and yeasts } \\
\hline $\begin{array}{l}\text { P. aeruginosa } \\
\text { EGYII DSM } \\
101801\end{array}$ & $\mathrm{SmF}$ & 8.5 & 45 & $\begin{array}{c}1121 \\
\mu \mathrm{mol} / \mathrm{min} / \mathrm{mg}\end{array}$ & $63.11 \mathrm{mM}$ & $\begin{array}{l}80 \%\left(37^{\circ} \mathrm{C}, 20 \mathrm{~min}\right) \\
20 \%\left(45^{\circ} \mathrm{C}, 10 \mathrm{~min}\right)\end{array}$ & - & $\begin{array}{c}\text { (El-Sharkawy et } \\
\text { al., 2016) }\end{array}$ \\
\hline $\begin{array}{l}\text { Aspergillus } \\
\text { oryzae CCT } \\
3940\end{array}$ & $\mathrm{SmF}$ & 8 & 50 & $313 \mathrm{IU} / \mathrm{mL}$ & $0.66 \mathrm{mM}$ & - & $\begin{array}{l}\text { Growth inhibition of } \\
\text { several human cancer } \\
\text { cell lines }\end{array}$ & (Dias et al., 2016) \\
\hline $\begin{array}{l}\text { Talaromyces } \\
\text { pinophilus }\end{array}$ & $\mathrm{SmF}$ & 8 & 28 & $\begin{array}{c}204 \\
\mu \mathrm{mol} / \mathrm{min} / \mathrm{mL}\end{array}$ & $6.4 \mathrm{mM}$ & - & - & $\begin{array}{l}\text { (Krishnapura \& } \\
\text { Belur, 2016) }\end{array}$ \\
\hline $\begin{array}{l}\text { Thermococcus } \\
\text { zilligii AN1 } \\
\text { TziAN1_1 }\end{array}$ & $\mathrm{SmF}$ & 8.5 & 90 & - & $6.08 \mathrm{mM}$ & $20 \%\left(90^{\circ} \mathrm{C}, 2 \mathrm{~h}\right)$ & $\begin{array}{l}\text { Reduction acrylamide } \\
\text { in French fries }\end{array}$ & (Zuo et al., 2015) \\
\hline \multicolumn{9}{|l|}{ Actinomycetes } \\
\hline $\begin{array}{l}\text { Streptomyces } \\
\text { sp. }\end{array}$ & $\mathrm{SmF}$ & 6 & 35 & $20.80 \mathrm{IU} / \mathrm{ml}$ & $0.065 \mathrm{mM}$ & - & - & $\begin{array}{c}\text { (Desai \& Hungund, } \\
\text { 2018) }\end{array}$ \\
\hline $\begin{array}{l}\text { S. fradiae } \\
N E A E-82\end{array}$ & $\mathrm{SmF}$ & 8.5 & 40 & $95.08 \mathrm{U} / \mathrm{ml}$ & $10.07 \mathrm{mM}$ & $50 \%\left(50{ }^{\circ} \mathrm{C}, 185 \mathrm{~min}\right)$ & Anticancer activity & $\begin{array}{c}\text { (El-Naggar et al., } \\
2016)\end{array}$ \\
\hline $\begin{array}{l}\text { Nocardiopsis } \\
\text { alba NIOT- } \\
\text { VKMAO8 }\end{array}$ & $\mathrm{SmF}$ & 8 & 37 & $5.50 \mathrm{U} / \mu \mathrm{g}$ & $0.127 \mathrm{mM}$ & - & Antineoplastic agent & $\begin{array}{l}\text { (Meena et al., } \\
\text { 2015) }\end{array}$ \\
\hline
\end{tabular}

*SmF and SSF: submerged fermentation and solid-state fermentation, respectively.

** Kinetic constants from Michaelis-Menten Equation: Vmax is the maximum reaction rate and $\mathrm{Km}$ is the Michaelis constant

Source: Authors. 


\subsection{Enzyme immobilization}

Immobilization technique have been revealed as a tool to improve almost all enzymatic properties, such as stability, activity, specificity, selectivity and reduction of inhibition, if properly prepared. However, to allow reuse of the enzyme, stability of the final preparation of these biocatalysts must be high; therefore, the enzyme must be very stable or highly stabilized during the immobilization process to be suitable (Mateo, Palomo \& Fernández-Lorente, 2007).

In the literature, different protocols for the immobilization of the enzyme have been reported. Immobilization occurs because the enzymes can be linked to different supports through various chemical interactions, such as physical adsorption, ionic bonds, covalent bonds and trapping. According to enzyme-support interactions, enzymatic immobilization methods can be classified in several forms. Classification represented in Figure 4 separate immobilization methods in which covalent reactions between enzyme and support occur from the methods in which only physical interaction or a barrier is responsible for enzyme immobilization, without any chemical reaction. All immobilization methods have certain advantages and disadvantages. The choice of the appropriate method depends on the characteristics of the enzyme, reaction medium and carrier material (Brena, González-Pombo \& Batista-Viera, 2013).

Figure. 4 - Classification of immobilization methods according to physical and chemical methods.

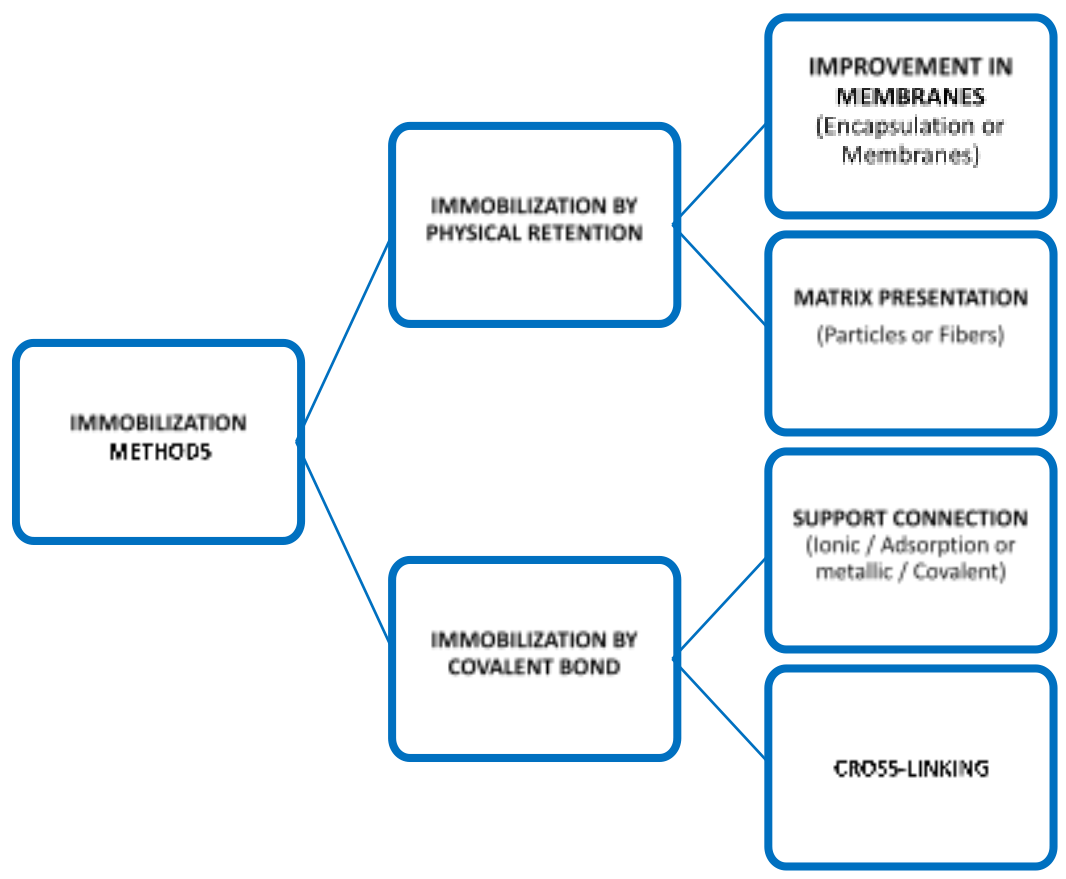

Source: Adapted from Brena et al. (2013)

\subsubsection{L-asparaginase immobilization}

Although L-asparaginase has been produced from a variety of sources, such as bacteria, yeasts, fungi, plants and actinomycetes, L-asparaginase of bacterial origin has a high molecular weight and, when exposed to the body's immune system for medication, its half-life decreases. Another restrictive factor due to its glutaminase activity, ovarian carcinomas and other solid tumors that were also designed as additional ASNase targets (Covini et al., 2011). Furthermore, when L-asparaginase is injected into the patient; it can cause severe hypersensitivity reactions, such as fever, skin rashes, allergic reactions and even anaphylactic shock (Ali et al., 2016) and rapid plasma clearance caused by native proteases in the blood system (Zhang et al., 2004). In addition, it is a drug with a high cost, but it is necessary in therapy, especially in children. When directed to food 
applications such as acrylamide reduction, food preparation conditions, such as temperature and $\mathrm{pH}$, can negatively influence its performance in reducing the amino acid asparagine (Verma et al., 2007). To overcome these limitations, enzymatic immobilization techniques that involve micro or nanoencapsulation of the enzyme prove to be promising strategies.

Encapsulation of L' asparaginase in sub-micro-sized structures entails several advantages, as in addition to meeting the difficulties presented above, the technique contributes to ensuring greater protection of the enzyme, possibility of its recovery, control over access to the catalytic center, increasing the its selectivity due to its ability to make its catalytic center easily accessible to substrates in order to contribute to the surface-volume relationship, in addition to presenting a high diffusion coefficient (Cellesi \& Tirelli, 2006). Therefore, an adequate encapsulation can protect an antibacterial enzyme from degradation, keeping it in active form while it is circulating in the body, in addition, the support structure (micro or nanocapsules) can add specific biological interactions, such as favoring a specific location of the action of the enzyme. Encapsulation helps to minimize adverse conditions that may eventually cause enzyme denaturation (Cellesi \& Tirelli, 2006), improving the drug's bioavailability, decreasing its toxicity and its ability to reach specific tissues, as shown in the works below.

Singh et al. (2020) explores the nanoformulation of long-acting crosslinker-free PLGA encapsulated by native Lasparaginase in an Ehrlich ascites tumor model. Tumor L-asparaginase-PLGA nanoparticles were prepared using the double emulsion solvent evaporation technique, optimized and validated by Box-Behnken Design. L-ASN-PNs showed a particle size of $195 \mathrm{~nm} \pm 0.2 \mathrm{~nm}$ and a PDI of 0.2. Scanning Electron Microscopy (SEM) and Transmission Electron Microscopy (TEM) techniques revealed its smooth morphology and produced an in vitro release of $80 \%$ of the drug, following the Higuchi drug release model. Mice treated with L-ASN-PN showed a 51.15\% decrease in tumor volume and $100 \%$ survival rate with no reduction in body weight, no hemotoxicity and no hepatotoxicity, demonstrating that L-Asparaginase PLGA nanoparticles are an entity suitable for better tumor regression, intratumoral accumulation and no hematological side effects.

Bahreini et al. (2014) found that the loading of L-asparaginase II (ASNase II) into chitosan nanoparticles (CSNPs) was confirmed by Fourier transform infrared spectroscopy (FTIR), and the morphological observation was performed by microscopy transmission electronics. Trapping efficiency and loading capacity increased with increasing concentration of chitosan (CS) and tripolyphosphate (TPP). The best ratio was applied to obtain optimal ASNase II loaded CSNPs with the highest trapping efficiency. Optimal size, zeta potential, trapping efficiency and carrying capacity of ASNase II-CSNPs were $340 \pm 12 \mathrm{~nm}, 21.2 \pm 3 \mathrm{mV}, 76.2 \%$ and $47.6 \%$, respectively. The immobilized enzyme showed an increased half-life in vitro compared to the free enzyme. The $\mathrm{pH}$ and thermostability of the immobilized enzyme were comparable to that of the free enzyme. This study leads to a better understanding of how to prepare CSNPs, how to achieve high encapsulation efficiency for a high molecular weight protein, and how to prolong protein release from CSNPs.

Orhan and Aktaş Uygun (2020) presented a study on magnetic poly nanoparticles (HEMA-GMA) that were synthesized, characterized and used for immobilization of the antileukemic enzyme L-asparaginase. The average particle size of the synthesized magnetic nanoparticles was $117.5 \mathrm{~nm}$. L-asparaginase was successfully immobilized on the synthesized magnetic nanoparticles and the fixed amount of L-asparaginase was $66.43 \mathrm{mg} / \mathrm{g}$ of nanoparticles. The optimal $\mathrm{pH}$ of free and immobilized L-asparaginase was 7.5 and 6.5 , respectively. The optimum temperature of free $\mathrm{L}$-asparaginase was $45^{\circ} \mathrm{C}$, while the optimum temperature was shifted to $55^{\circ} \mathrm{C}$ after immobilization on magnetic nanoparticles. In addition, the $\mathrm{K}_{\text {cat }}$ value of free L-asparaginase $\left(47,356 \mathrm{~min}^{-1}\right)$ was calculated to be greater than that of immobilized L-asparaginase $\left(497 \mathrm{~min}^{-1}\right)$. The thermal stability of both asparaginase preparations was monitored for 10 hours and, at the end of the incubation time, the free asparaginase almost lost its activity, while the immobilized asparaginase protected $50 \%$ of its initial activity. The storage stabilities of free and immobilized asparaginase were also tested and, at the end of 40 days of storage, free asparaginase lost all 
Research, Society and Development, v. 10, n. 10, e596101018980, 2021

(CC BY 4.0) | ISSN 2525-3409 | DOI: http://dx.doi.org/10.33448/rsd-v10i10.18980

its activity, while immobilized asparaginase still had $30 \%$ activity.

Agrawal and Kango (2019) describe the efficient immobilization of L-glutaminase-free L-asparaginase for the development of a new therapeutic system for anticancer therapy. L-asparaginase (L-ASNase) was covalently immobilized on functionalized aluminum oxide nanoparticles (AONP) and titanium oxide nanoparticles (TONP). The nano bioconjugates (AONP-ASNase and TONP-ASNase) were characterized by scanning electron microscopy (SEM), Fourier transform infrared spectroscopy (FTIR) and UV-Vis spectral analysis. The nano-bioconjugates were optimally active at $\mathrm{pH} 7.0$ and $40{ }^{\circ} \mathrm{C}$. The TONP-ASNase activity was increased in the presence of $\mathrm{NH}_{4}^{+}(160 \%)$ and $\mathrm{Mn}_{2}^{+}(165 \%)$ while the AONP-ASNase bioconjugates showed higher relative activity with ethyl acetate $(142 \%)$ and toluene (160\%). The nanobioconjugates exhibited excellent reusability and maintained $>90 \%$ mean activity after nine successive cycles. Maximum cytotoxicity (61\%) was observed with AONP-ASNase $(10 \mu \mathrm{g} / \mathrm{ml})$ against MOLT-4 human leukemia cells. Regarding kinetic values, AONP-ASNase showed better affinity $(\mathrm{Km} 1.9 \mu \mathrm{mol})$ to L-asparagine compared to G-free ASNase. After 23 days of storage at $37{ }^{\circ} \mathrm{C}$, the bioconjugates retained $40 \%$ of the residual activity while free L-ASNase was completely deactivated. Thermodynamic characterization revealed a higher conversion rate of the ES complex in the case of nano-bioconjugates.

In addition to asparaginase immobilization methods involving micro or nanoencapsulation systems, other authors, as shown below, have developed studies using other immobilization methods, such as cross-linking, physical adsorption, ionic bonding, among others, in order to improve properties and kinetic parameters of L'asparaginase when directed to applicational purpose. Studies evaluating different immobilization methods of L-asparaginase are presented in Table 2. These studies showed that immobilization may increase enzyme affinity for the substrate, increase enzyme thermostability and shelf life and allows enzyme reuse for several cycles with minor loss of activity. Some of these studies also evaluated the effect of the immobilized enzymes in acrylamide reduction in food and cytotoxic effect against cancer cells. 


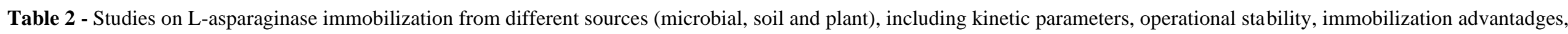
applications.

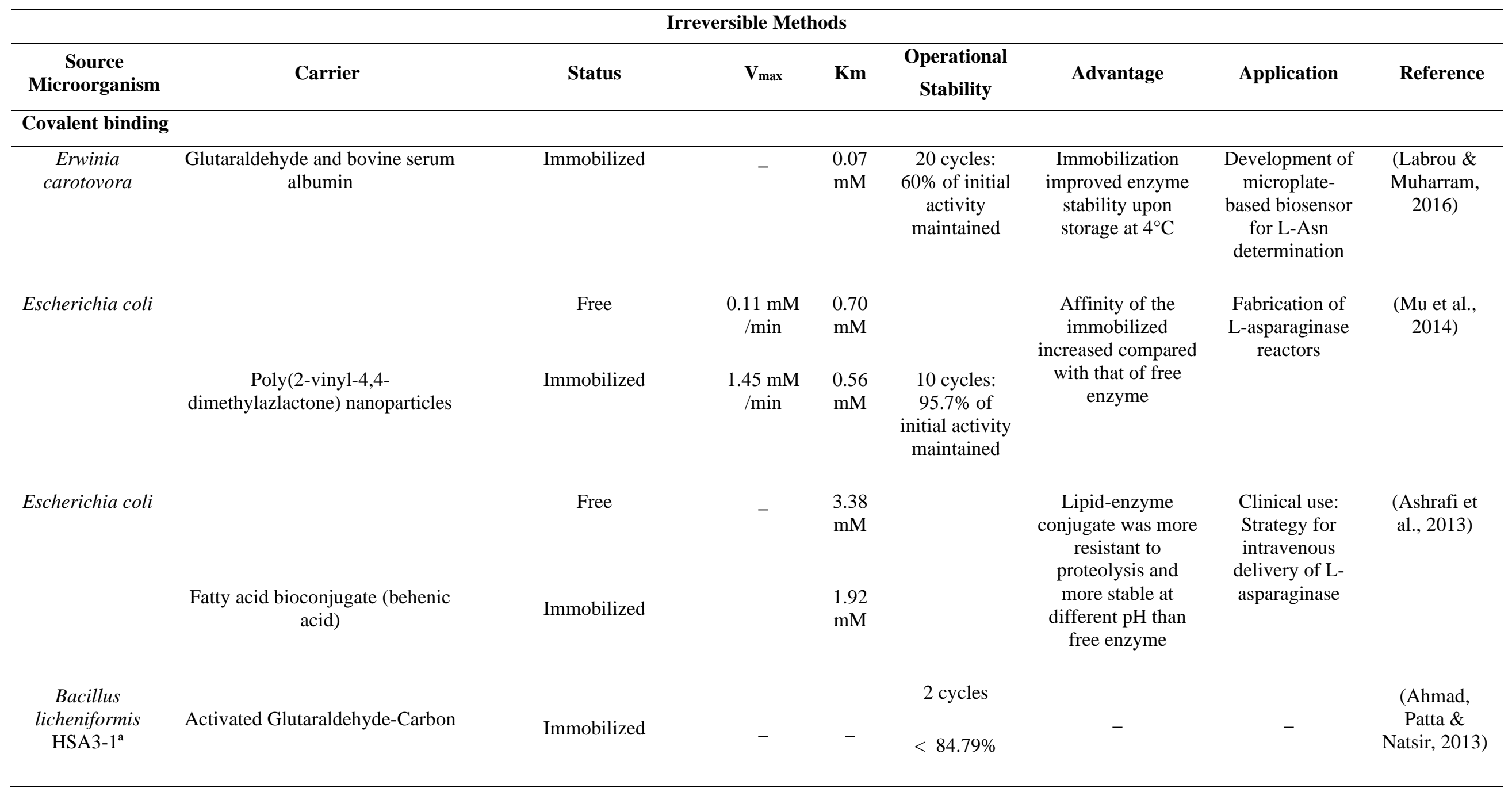




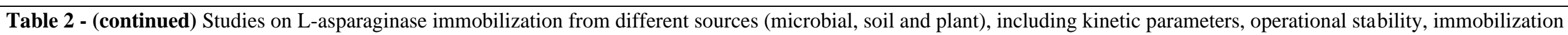
advantadges, applications.

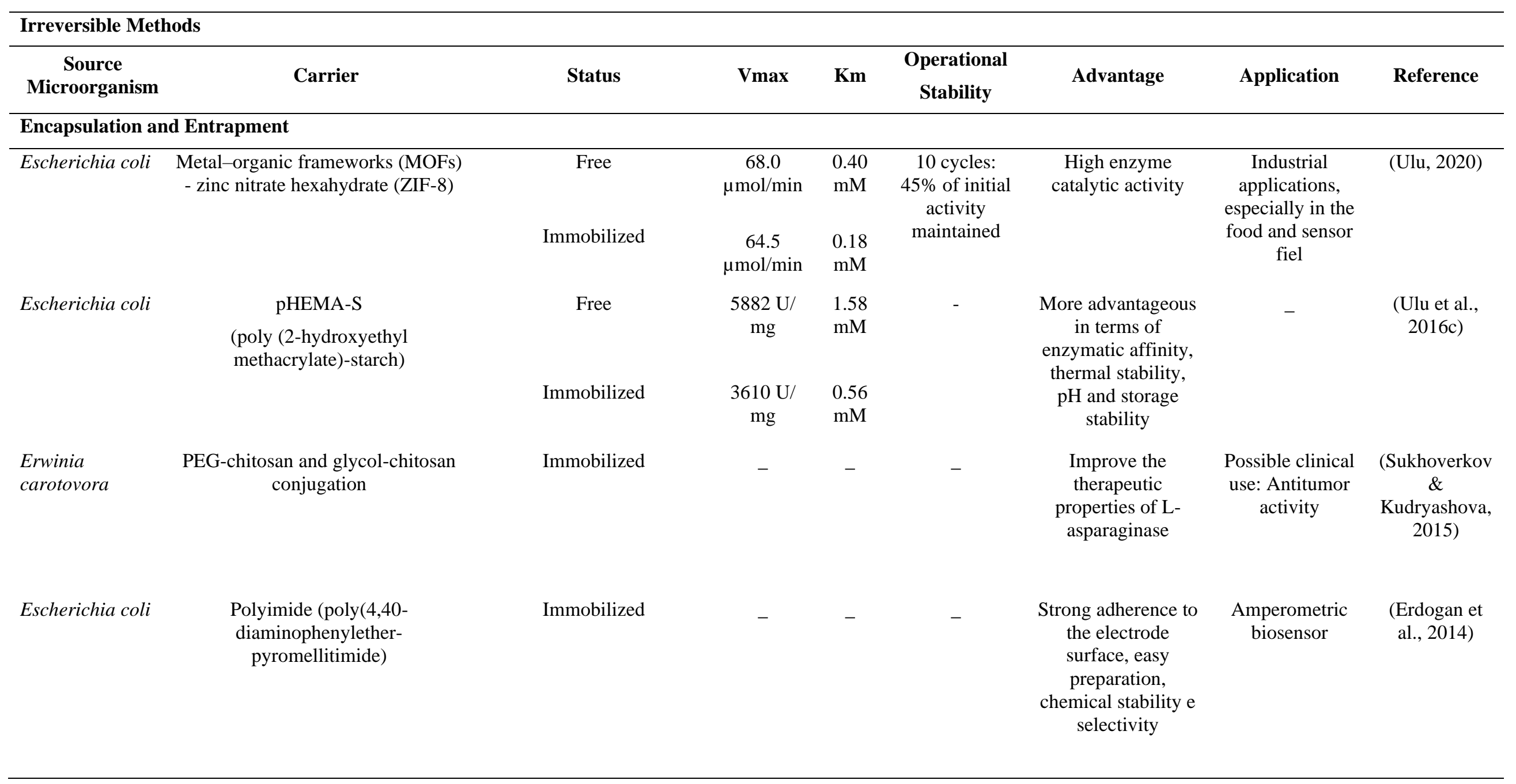




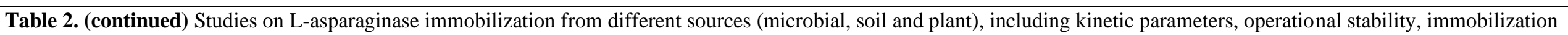
advantadges, applications.

\begin{tabular}{|c|c|c|c|c|c|c|c|c|}
\hline \multicolumn{9}{|c|}{ Irreversible Methods } \\
\hline $\begin{array}{l}\text { Source } \\
\text { Microorganism }\end{array}$ & Carrier & Status & Vmax & $\mathbf{K m}$ & $\begin{array}{l}\text { Operation } \\
\text { Stability }\end{array}$ & Advantage & Application & Reference \\
\hline \multicolumn{9}{|c|}{ Encapsulation and Entrapment } \\
\hline Escherichia coli & $\begin{array}{l}\text { Poly(dextran/L-arginine)- } \\
\mathrm{CaCO} 3\end{array}$ & Immobilized & - & - & - & $\begin{array}{c}\text { Thermal } \\
\text { improvement, } \\
\text { stability at } \\
\text { physiological } \\
\text { temperature and at } \\
\text { long term storage }\end{array}$ & - & $\begin{array}{l}\text { (Karamitros } \\
\text { et al., 2013) }\end{array}$ \\
\hline \multicolumn{9}{|c|}{ Reversible Methods } \\
\hline \multicolumn{9}{|l|}{ Ionic binding } \\
\hline Escherichia coli & $\begin{array}{l}\text { Aluminum oxide pellets } \\
\text { (AlOPs) }\end{array}$ & Immobilized & $\begin{array}{c}20.8 \mathrm{x} \\
10^{-3} \\
\mathrm{mM} / \mathrm{min} \\
8.2 \times 10^{-3} \\
\mathrm{mM} / \mathrm{min}\end{array}$ & $\begin{array}{c}12.8 \mathrm{x} \\
10^{-3} \\
\mathrm{mM} \\
5.39 \mathrm{x} \\
10^{-3} \\
\mathrm{mM}\end{array}$ & $\begin{array}{l}83 \% \text { of initial } \\
\text { activity } \\
\text { retained after } \\
9 \text { cycles }\end{array}$ & $\begin{array}{l}\text { Improvement on } \\
\text { substrate affinity, } \\
\text { on pH and thermal } \\
\text { stability; reuse with } \\
\text { minor activity loss, } \\
\text { long shelf life }\end{array}$ & $\begin{array}{l}\text { Reduction of L- } \\
\text { asparagine in } \\
\text { blanched potato }\end{array}$ & $\begin{array}{c}\text { (Agrawal et } \\
\text { al., 2018) }\end{array}$ \\
\hline $\begin{array}{l}\text { Penicillium } \\
\text { cyclopium }\end{array}$ & Amberlite IR-120 & Immobilized & $\begin{array}{l}757.6 \\
\mathrm{U} / \mathrm{mg}\end{array}$ & $\begin{array}{l}33 \mathrm{x} \\
10^{-3} \\
\mathrm{mM} \\
25.9 \mathrm{x} \\
10^{-3} \\
\mathrm{mM}\end{array}$ & $70 \%$ & $\begin{array}{l}\text { Optimal activity to } \\
\text { several pH values, } \\
\text { higher } \\
\text { thermostability and } \\
\text { affinity to the } \\
\text { substrate }\end{array}$ & - & $\begin{array}{l}\text { (El-Refai et } \\
\text { al., 2016) }\end{array}$ \\
\hline \multicolumn{9}{|l|}{ Adsorption } \\
\hline Escherichia coli & $\begin{array}{c}\text { DPPC (phospholipid } \\
\text { dipalmitoylphosphatidylcholine) }\end{array}$ & Immobilized & - & - & - & $\begin{array}{l}\text { Higher shelf life } \\
\text { than free enzyme }\end{array}$ & $\begin{array}{l}\text { Langmuir lipid } \\
\text { monolayers }\end{array}$ & $\begin{array}{c}\text { (Rocha } \\
\text { Junior \& } \\
\text { Caseli, 2017) }\end{array}$ \\
\hline
\end{tabular}




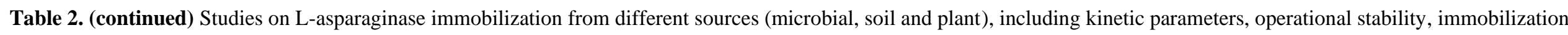
advantadges, applications.

\begin{tabular}{|c|c|c|c|c|c|c|c|c|}
\hline \multicolumn{9}{|c|}{ Methods Reversible } \\
\hline $\begin{array}{c}\text { Source } \\
\text { Microorganism }\end{array}$ & Carrier & Status & Vmax & $\mathbf{K m}$ & $\begin{array}{l}\text { Operation } \\
\text { Stability }\end{array}$ & Advantage & Application & Reference \\
\hline \multicolumn{9}{|l|}{ Adorption } \\
\hline $\begin{array}{l}\text { Acinetobacter } \\
\text { baumannii }\end{array}$ & Silica gel - Sephadex G-50 & Immobilized & - & - & $\begin{array}{c}\geq 90 \% \text { of } \\
\text { activity } \\
\text { preserved } \\
\text { after } 4 \text { weeks }\end{array}$ & $\begin{array}{l}\text { High stability in } \\
\text { long term storage }\end{array}$ & & $\begin{array}{l}\text { (Muslim, } \\
\text { Kadmy \& } \\
\text { Hussein, } \\
\text { 2015) }\end{array}$ \\
\hline $\begin{array}{l}\text { Escherichia coli } \\
\text { BL21pLysS }\end{array}$ & $\begin{array}{c}\text { Chitosan-tripolyphosphate } \\
\text { nanoparticles }\end{array}$ & Immobilized & & - & - & $\begin{array}{l}\text { Increased in vitro } \\
\text { half-life in } \\
\text { comparison with the } \\
\text { free enzyme }\end{array}$ & & $\begin{array}{l}\text { (Bahreini et } \\
\text { al., 2014b) }\end{array}$ \\
\hline
\end{tabular}


To stabilize the quaternary structure of multimeric enzymes, a strategy based on covalent immobilization of several units of the enzyme on activated supports (agarose-glutaraldehyde) was developed. Activated supports have different densities of reactive groups; the higher the density of the groups, the greater the stabilization achieved. Nevertheless, when targeting complex enzymes, even with the use of higher densities of reactive groups, it is not possible to cover all four subunits in the immobilization process, demanding additional chemical intersubunit cross-links with aldehyde-dextran. With this procedure, Balcão et al. (2001) managed to stabilize the quaternary structure of L-asparaginase from E. coli by covalent immobilization with several subunits of the enzyme. The support used was agarose, which was subjected to crosslinking with glutaraldehyde, and chemical crosslinking of additional intersubunit with aldehyde-dextran to obtain a multimeric structure, fully stabilized, preventing inactivation of the enzyme by the dissociation subunit, and improving its thermostability.

Zhang et al. (2004) immobilized L-asparaginase covalently by polar groups on the surfaces of sericin microparticles (a globular protein derived from the Bombyx mori cocoon) using glutaraldehyde. The immobilized enzyme showed an affinity for the substrate eight times greater than native asparaginase. Ghosh, Chaganti and Prakasham (2012) immobilized Lasparaginase with polyaniline nanofibers and observed greater stability and activity, which may have been due to conformational changes in the enzyme through ionic interactions with polyaniline nanofibers. The L-asparagine microplate biosensor project was developed by Labrou and Muharram (2016) presenting high sensitivity, low cost and good stability and selectivity, which contribute considerably to applications in food and clinical chemistry, providing a new approach for measurement and also for specific, economically viable and fast analyses of L-asparagine. The L-asparaginase enzyme from E, carotovora was immobilized by crosslinking with glutaraldehyde and bovine serum albumin (BSA). While the free enzyme completely lost its activity after 8 days of incubation at $4{ }^{\circ} \mathrm{C}$, the immobilized enzyme maintained about $50 \%$ of its intrinsic activity after about 30 days of storage. The biosensor showed high sensitivity for the detection of L-asparagine with a linear range of 10 to $200 \mu \mathrm{M}$. The method's reproducibility was in the order of $\pm 3-6 \%$, and L-asparagine mean recovery was $101.5 \%$.

El-Refai et al. (2016) reported successful immobilization and improved stabilization of L-asparaginase in Amberlite IR-120 by ionic bond. Immobilization did not change the ideal $\mathrm{pH}(8.0)$ or temperature $\left(40{ }^{\circ} \mathrm{C}\right)$ compared to the free enzyme, but it showed greater thermostability as a result of the immobilization. The immobilized enzyme retained $100 \%$ of activity when exposed to $60{ }^{\circ} \mathrm{C}$, and also retained $70 \%$ of its activity relative to $\mathrm{pH} 9.0$ for 50 min. Rocha Junior and Caseli (2017) immobilized L-asparaginase in monolayers of the phospholipid dipalmitoylphosphatidylcholine (DPPC) chosen based on abundance in several cells. The enzyme immobilized in the ultrathin lipid films preserved more than $78 \%$ of the enzymatic activity after 30 days while the homogeneous medium preserved less than $13 \%$. Therefore, lipid films are an adequate carrier matrix to protect L-asparaginase activity and can also be considered for the detection of asparagine, hence revealing that ultrathin lipid films (Langmuir e Langmuir-Blodgett) can be used to immobilize L-asparaginase by adsorption.

Recently, studies on permeable polymers such as polyethylene glycol (PEG) as nanoreactors from ASNA (Lasparaginase) have been developed by Blackman et al. (2018). PEG is a non-immunogenic polymer commonly conjugated to proteins (PEGylation) to increase its hydrodynamic volume that reduces glomerular filtration and improves biological half-life. Polymerization-induced self-assembly (PISA) used for encapsulation of clinical biological ASNS inside inert vesicles and selectively permeable in size protects it from proteases and recognition by antibodies. These polymersome materials lead to depletion of L-asparagine without releasing ASNS from the nanostructures into the bloodstream, consequently reducing proteolytic degradation of the enzyme and recognition of antibodies in comparison with the free protein or protein conjugated with PEGylation. Ulu (2020) analyzed metal-organic frameworks (MOFs), verifying that these materials have a huge surface area, large porosity and tunable functionality, aspects that are positive for carrying out enzyme immobilization tests, specifically for L-asparaginase. After enzymatic immobilization, the author found that the ideal temperature changed from 50 
to $60{ }^{\circ} \mathrm{C}$, while the ideal $\mathrm{pH}$ remained unchanged at 9.0. ASNase @ ZIF-8 exhibited excellent long-term storage stability (56\% of initial activity at $25^{\circ} \mathrm{C}$ for 4 weeks).

Based on the studies presented in this work, it appears that processes that use the nano, or microencapsulation or other differents methods of immobilization of L-asparaginase such as adsorption, covalent, ionic bonding, encapsulation and entrapment, presented better enzymatic properties when compared to the free enzyme. Properties are how much it increased half-life, significantly greater stability to allergic reactions compared to the free enzyme for clinical use, and better stability of enzymatic activity when directed to reduce acrylamide for food use.

\subsection{L-asparaginase Food Industry Application: Acrylamide Reduction}

According to Panel and Chain (2015), the intake of acrylamide in global diet is estimated to be between 0.3 and 1.9 $\mu \mathrm{g} / \mathrm{kg}$ orally; however, foods with the greatest contribution to this intake vary from country to country, according to food standards and preparation methods Claus, Carle and Schieber (2008). Among factors that influence the formation of acrylamide in food are processing conditions (temperature, humidity, cooking time and product matrix) and its precursors, such as reducing sugars and free amino acids like L-asparagine (Zuo et al., 2015).

The Federal Food and Drug Administration (FDA) together with the European Food Safety Authority (EFSA) have carried out extensive research on the content of acrylamide present in different food products, analyzing levels of toxicity in humans. Results were published as various review and scientific manuscripts regarding the amount of acrylamide formation in different types of food products, and also the formation of other contaminants in the heat-processed food system. The observed results showed that the main food groups, the ones that contribute the most to acrylamide exposure, are French fries, bakery products and coffee (Outcome of the public consultation on the draft Scientific Opinion of the EFSA Panel on Contaminants in the Food Chain (CONTAM) on acrylamide in food 2017). Since then, studies have been carried out to understand the mechanisms of acrylamide formation and to develop reduction strategies.

The reduction of acrylamide in French fries has been tested by different authors. A 90\% reduction was achieved when bleaching $\left(85^{\circ} \mathrm{C}\right.$ for $3.5 \mathrm{~min}$ ) was applied, followed by immersion in solution of L-asparaginase from Aspergillus oryzae (50 ${ }^{\circ} \mathrm{C}$ for $20 \mathrm{~min}$ ). The heat treatment was able to cause changes in structure, facilitating diffusion of the enzyme in tissues, and consequently favoring and improving its action (Pedreschi et al., 2011). Another research was used L-asparaginase synthesized by Fusarium culmorum (ASP-87) used to reduce acrylamide in potato-based products. Fries were treated with the enzyme at $40{ }^{\circ} \mathrm{C}$ for $30 \mathrm{~min}$, followed by frying at temperatures of $170-180^{\circ} \mathrm{C}$ for $90 \mathrm{~s}$. It was observed that $300 \mathrm{U} / \mathrm{L}$ L-asparaginase was needed to reduce $85 \%$ to $94 \%$ of acrylamide levels in French fries (Meghavarnam \& Janakiraman, 2018) . Mohan Kumar \& Manonmani (2013) produced, purified and characterized a new L-asparaginase Cladosporium sp., which was able to reduce levels of acrylamide in potato snacks by up to $96 \%$.

Anese, Quarta and Frias (2011) found that the use of intermediate concentrations of L-asparaginase of $500 \mathrm{U} / \mathrm{Kg}$ resulted in minimal acrylamide formation in shorter time and lower incubation temperature, while reporting that the color parameter of the cookie was not affected by the application of the enzyme. The L-asparaginase gene from Rhizomucor miehei has been cloned and expressed in E. coli (Huang et al., 2014), and the synthesized and purified enzyme (10 U/mg of flour) was used to reduce the level of acrylamide in cookies, reaching a reduction of approximately $80 \%$, being also useful in reducing acrylamide present in the breads. Mohan Kumar et al. (2014) applied different concentrations of L-asparaginase produced from Cladosporium sp. on sweet bread. The authors did not observe changes in the physical-sensory characteristics of bread with treatment with L-asparaginase. Specifically, there was a reduction of $97 \%$ and $73 \%$ in the formation of acrylamide in the regions of dough and on the outside of the bread (crust), respectively in the treatment with $300 \mathrm{U}$. According to the authors, these results indicate the potential of L-asparaginase for reducing acrylamide with industrial and domestic application. The 
same enzyme was tested to reduce levels of acrylamide in loaf bread, being able to reduce by up to $97 \%$ of this compound in the bread crust, where the Maillard reaction occurs with greater prominence.

Along with potatoes and cereal products, roasted coffee is one of the products with high concentration of acrylamide (Mesias et al., 2018), being present in the two main coffee species most consumed worldwide, Coffea arabica and Coffea canefhora. Coffee has high levels of acrylamide due to the roasting process $\left(105^{\circ} \mathrm{C}\right)$, and storage conditions can also contribute to the formation of this compound (Mesías \& Morales, 2016). Exposure to acrylamide resulting from roasted coffee consumption varies from country to country, age and sex of the consumer, volume of coffee ingested, degree of roasting, etc (Anese, 2016). Consequently, daily intake of this product represents a significant source of exposure to acrylamide (Şenyuva \& Gökmen, 2005). Hendriksen et al. (2009) evaluated the effect of L-asparaginase on reducing acrylamide in coffee. Green grains of Arabica species were steamed with water for 45 minutes at $100{ }^{\circ} \mathrm{C}$, and subsequently treated with $\mathrm{L}$-asparaginase at $60{ }^{\circ} \mathrm{C}$ for $60 \mathrm{~min}$. The authors observed the greatest reduction when they used an enzyme concentration of $6000 \mathrm{U} / \mathrm{kg}$ that resulted in a reduction of 70 to $80 \%$ of L-asparagine content, and 55-74\% in the formation of acrylamide. Another work developed by $\mathrm{Xu}$, Oruna-Concha and respectively.

As for particulate systems involving the nano or microencapsulation of the immobilized L'asparaginase enzyme, so far there are few works that have developed methods addressing their use for the reduction of acrylamide in foods, as they are considered recent but promising technologies for the field of food science that examines the removal of acrylamide from various food products. Among these few works, Alam et al. (2018) verified that immobilized l-asparaginase in APTESmodified magnetic nanoparticles exhibited an increase in the thermal stability of the free enzyme in more than three times, retaining $90 \%$ of the activity after the fifth cycle, it was found that the immobilized enzyme also showed better affinity with its substrate and during the pretreatment of asparagine in a model system of food starch-asparagine the study showed that the asparaginase nanoconjugates reduced the formation of acrylamide by more $90 \%$ in $30 \mathrm{~min}$.

Improved stability of ASNase for acrylamide mitigation in potato chips by immobilization on magnetic NPs was described by Ravi Aiswarya and Baskar (2018) who reported operating system improvement without loss of enzymatic activity during three reuse cycles and a reduction in acrylamide of about $75 \%$. Other supports investigated recently involve aluminum oxide pellets (AlOPs).

The enzymatic treatment was able to reduce levels of acrylamide in all tested products that have high amounts of this compound. In all the various studies presented above authors concluded that thermal bleaching was able to improve the effect on the reduction of acrylamide. Thermal bleaching can occur in two different stages: the first is thermal treatment (heated solution) without the enzyme and a second thermal treatment with the enzyme (heat treatment together with the enzyme). The strategy of using L-asparaginase is relatively new, mainly when directing to the micro or nanoencapsulation of l'asparagnase in food systems, however promising, and an excellent technique for reducing acrylamide in food. This enzyme helps in two-way mitigation strategies, interference with the Maillard reaction or removal of precursors by converting L-asparagine to L-aspartic acid (non-toxic) without changing nutritional value, appearance or taste of the final product (Batool et al., 2016; Hendriksen et al., 2009).

Time, temperature and enzyme loading are important parameters to be determined in treatment of foods with 1asparaginase. These treatments conditions can vary with enzyme source and type of food, and also resulted in different acrylamide reduction. In the studies presented in Table 3, enzyme dose varied from $0.3 \mathrm{U} / \mathrm{ml}$ to $50 \mathrm{U} / \mathrm{ml}$, time and temperature of soaking varied from 4 to $30 \mathrm{~min}$ and $37^{\circ} \mathrm{C}$ to $80^{\circ} \mathrm{C}$, respectively. Acrylamide reduction ranged from $55 \%$ for potato chips, using E. coli enzyme, to $97 \%$ in bread crush, in which an enzyme from Cladosporium sp. was used. Other conditions that influence acrylamide formation is the frying or roasting temperature and time, oil nature and pre-treatment used (Onishi et al., 2015; Aiswarya \& Baskar, 2018a; Aiswarya \& Baskar, 2018b). 
Table 3 - Use of 1-asparaginase in food: enzyme source, food model, enzymatic reaction conditions and \% of acrylamide reduction.

\begin{tabular}{|c|c|c|c|c|}
\hline $\begin{array}{l}\text { Enzyme Source - } \\
\text { Microorganism }\end{array}$ & Food model & $\begin{array}{l}\text { Optimized conditions - Temperature }\left({ }^{\circ} \mathrm{C}\right) \text {, Time } \\
\text { (min) e Enzimatic Charge }(\mathrm{U} / \mathrm{L} \text { or } \mathrm{U} / \mathrm{mL})\end{array}$ & Acrylamide Reduction & Reference \\
\hline Acinetobacter soli & Potato chips & $37^{\circ} \mathrm{C} / 30 \mathrm{~min} / 30 \mathrm{U} / \mathrm{mL}$ & $55.9 \%$ & (Jiao et al., 2020) \\
\hline Fusarium culmorum & Sweet bread & $40^{\circ} \mathrm{C} / 30 \mathrm{~min} / 0.3 \mathrm{U} / \mathrm{mL}$ & $86 \%$ & $\begin{array}{c}\text { (Meghavarnam \& Janakiraman, } \\
\text { 2018) }\end{array}$ \\
\hline Fusarium culmorum & Potato chips & $40^{\circ} \mathrm{C} / 30 \mathrm{~min} / 0.3 \mathrm{U} / \mathrm{mL}$ & $94 \%$ & $\begin{array}{c}\text { (Meghavarnam \& Janakiraman, } \\
\text { 2018) }\end{array}$ \\
\hline Aspergillus terreus & Carrot slices & $50{ }^{\circ} \mathrm{C} / 15 \mathrm{~min} / 3 \mathrm{U} / \mathrm{mL}$ & $\begin{array}{l}\text { up to } 65 \% \text {, depending } \\
\text { on roasting time and } \\
\text { temperature }\end{array}$ & (Aiswarya \& Baskar, 2018a) \\
\hline Aspergillus terreus & Fried blanched potatoes & $50{ }^{\circ} \mathrm{C} / 30 \mathrm{~min} / 4 \mathrm{U} / \mathrm{mL}$ & $\begin{array}{l}\text { up to } 70 \% \text {, depending } \\
\text { on frying time and } \\
\text { temperature }\end{array}$ & ( Aiswarya \& Baskar, 2018b) \\
\hline Aspergillus terreus & Banana slices (Kochchi kesel) & $60^{\circ} \mathrm{C} / 20 \mathrm{~min} / 5 \mathrm{U} / \mathrm{ml}$ & $\begin{array}{l}\text { up to } 70 \% \text {, depending } \\
\text { on frying time and } \\
\text { temperature }\end{array}$ & (Ravi \& Gurunathan, 2018) \\
\hline Aspergillus oryzae & French fries & $50^{\circ} \mathrm{C} / 30 \mathrm{~min} / 50 \mathrm{U} / \mathrm{mL}$ & $72 \%$ & (Dias et al., 2017) \\
\hline Thermococcus zilligii & French fries & $80^{\circ} \mathrm{C} / 4 \mathrm{~min} / 10 \mathrm{U}$ & $80.5 \%$ & (Zuo et al., 2015) \\
\hline Bacillus subtilis & Pre-treated sliced potatoes & $60^{\circ} \mathrm{C} / 10 \mathrm{~min} / 40 \mathrm{U}$ & $>80 \%$ & (Onishi et al., 2015) \\
\hline Cladosporium sp & Sweet bread & $\begin{array}{l}300 \mathrm{U} \text { incorporated into dough at the beginning of } \\
\text { the preparation }\end{array}$ & $\begin{array}{l}97 \% \text { in the crush } \\
73 \% \text { in the crumb }\end{array}$ & (Mohan Kumar et al., 2014) \\
\hline
\end{tabular}




\section{Conclusion}

L-asparaginase has been targeted for therapeutic use and studied for decades as a limiter of the amino acid asparagine, inhibiting the formation of carcinogenic compounds. In the food industry, the use of the biocatalyst L-asparaginase is related to a reduction of the acrylamide compound in thermal processed foods since the availability of free amino acids such as asparagine together with reducing sugars (carbonyl groups) during the Maillard reaction, contributes to the synthesis of acrylamide.

Studies in the literature presented in this review showed a diversity of microbial enzyme sources, enzyme kinetic characteristics, stability, immobilization methods and conditions of enzyme applications in food and anticancer efficiency of the enzyme. For leukemia treatment, besides enzymes with high activity and stability in physiological pH and temperature, it is important to evaluate possible side effects, as hemolysis or toxicity on human normal cells. As food matrices have a wide range of $\mathrm{pH}$, and processing temperature may vary, enzymes with different optimum $\mathrm{pH}$ and temperature, and thermal stability are suitable.

The process of synthesizing L-asparaginase and its purification is one of the biggest challenges regarding its application. Processing the enzyme has a high cost, consequently making the product less accessible. For this reason, studies looking for super producers of 1-asparaginase and optimization of production and purification conditions are still needed in order to reduce enzyme prices. Another issue that hinders its use for application purposes (food/therapeutic) is that the enzyme is limited in terms of stability in the reaction medium and, in many cases, there is no possibility of reuse. Immobilization is a strategy that can overcome some of these drawbacks, as it result in enzymes with higher affinity and stability, and allow enzyme reuse. Most recently, nano and microencapsulation has emerged, improving mass transfer and, therefore, increasing reaction rate. Hence, this method has been increasingly used and is replacing conventional methods in several sectors of the industry, for presenting efficiency and faster performance in comparison the use of chemical catalysts and free enzyme. However, there is still a lack in the literature about biocompatible supports for immobilization, which would allow application for leukemia treatment and in foods.

\section{References}

Agarwal, S., \& Sahu, S. (2014). Safety and Regulatory Aspects of Food Enzymes: An Industrial Perspective. International Journal of Interdisciplinary and Multidisciplinary Studies (IJIMS), 1(6), 253-267. http://www.ijims.com/uploads/0078a9c56ca7560ca162z32.pdf

Agrawal, S., \& Kango, N. (2019). Development and catalytic characterization of L-asparaginase nano-bioconjugates. International Journal of Biological Macromolecules, 135, 1142-1150. 10.1016/j.ijbiomac.2019.05.154

Agrawal, S., Sharma, I., Prajapati, B. P., Suryawanshi, R. K., \& Kango, N. (2018). Catalytic characteristics and application of L-asparaginase immobilized on aluminum oxide pellets. International Journal of Biological Macromolecules, 114, 504-511. 10.1016/j.ijbiomac.2018.03.081

Ahmad, A., Patta, A. M., \& Natsir, H. (2013). Purification and immobilization of L-asparaginase enzyme from the thermophilic bacteria Bacillus licheniformis strain HSA3-1a. International Journal of Pharma and Bio Sciences, 4(4), 274-280.

Aiswarya, R., \& Baskar, G. (2018). Microbial production of 1-asparaginase and its immobilization on chitosan for mitigation of acrylamide in heat processed carrot slices. Indian Journal of Experimental Biology, 56(7), 504-510.

Aiswarya, Ravi, \& Baskar, G. (2018). Enzymatic mitigation of acrylamide in fried potato chips using asparaginase from Aspergillus terreus. International Journal of Food Science and Technology, 53(2), 491-498. 10.1111/ijfs.13608

Alam, S., Ahmad, R., Pranaw, K., Mishra, P., \& Khare, S. K. (2018). Asparaginase conjugated magnetic nanoparticles used for reducing acrylamide formation in food model system. Bioresource Technology, 269, 121-126. 10.1016/j.biortech.2018.08.095

Anese, M. (2016). Acrylamide in Coffee and Coffee Substitutes. In V. Gökmen (Ed.), Acrylamide in Food: Analysis, Content and Potential Health Effects (pp. 181-195). Elsevier Inc. 10.1016/B978-0-12-802832-2.00009-7

Anese, M., Quarta, B., \& Frias, J. (2011). Modelling the effect of asparaginase in reducing acrylamide formation in biscuits. Food Chemistry, 126(2), 435- 
Research, Society and Development, v. 10, n. 10, e596101018980, 2021 (CC BY 4.0) | ISSN 2525-3409 | DOI: http://dx.doi.org/10.33448/rsd-v10i10.18980

440. 10.1016/j.foodchem.2010.11.007

Ashrafi, H., Amini, M., Mohammadi-Samani, S., Ghasemi, Y., Azadi, A., Tabandeh, M. R. \& Kamali-Sarvestani (2013). Nanostructure 1-asparaginase-fatty acid bioconjugate: Synthesis, preformulation study and biological assessment. International Journal of Biological Macromolecules, 62, 180-187. 10.1016/j.ijbiomac.2013.08.028

Bahreini, E., Aghaiypour, K., Abbasalipourkabir, R., Mokarram, A. R., Goodarzi, M. T., \& Saidijam, M. (2014). Preparation and nanoencapsulation of 1asparaginase II in chitosan-tripolyphosphate nanoparticles and in vitro release study. Nanoscale Research Letters, 9(1), 1-13. 10.1186/1556-276X-9-340

Bakshi, A., \& Patel, A. K. (2019). Halftoning algorithm using pull-based error diffusion technique. Lecture Notes in Networks and Systems, 56, 411-419. 10.1007/978-981-13-2354-6_43

Balcão, V. M., Mateo, C., Fernández-Lafuente, R., Xavier Malcata, F., \& Guisán, J. M. (2001). Structural and functional stabilization of L-asparaginase via multisubunit immobilization onto highly activated supports. Biotechnology Progress, 17(3), 537-542. 10.1021/bp000163r

Baskar, G., Chandhuru, J., Sheraz Fahad, K., Praveen, A. S., Chamundeeswari, M., \& Muthukumar, T. (2015). Anticancer activity of fungal 1-asparaginase conjugated with zinc oxide nanoparticles. Journal of Materials Science: Materials in Medicine, 26(1), 1-7. 10.1007/s10856-015-5380-Z

Batool, T., Makky, E. A., Jalal, M., \& Yusoff, M. M. (2016). A Comprehensive Review on 1-Asparaginase and Its Applications. Applied Biochemistry and Biotechnology, 178(5), 900-923. 10.1007/s12010-015-1917-3

Bilal, M., Zhao, Y., Rasheed, T., \& Iqbal, H. M. N. (2018, December 1). Magnetic nanoparticles as versatile carriers for enzymes immobilization: A review. International Journal of Biological Macromolecules, 120, 2530-25-44. 10.1016/j.ijbiomac.2018.09.025

Blackman, L. D., Varlas, S., Arno, M. C., Houston, Z. H., Fletcher, N. L., Thurecht, K. J. \& Hasan, M. (2018). Confinement of Therapeutic Enzymes in Selectively Permeable Polymer Vesicles by Polymerization-Induced Self-Assembly (PISA) Reduces Antibody Binding and Proteolytic Susceptibility. ACS Central Science, 4(6), 718-723. 10.1021/acscentsci.8b00168

Brena, B., González-Pombo, P., \& Batista-Viera, F. (2013). Immobilization of enzymes: A literature survey. Methods in Molecular Biology, 1051, 15-31. 10.1007/978-1-62703-550-7_2

Cellesi, F., \& Tirelli, N. (2006). Sol-gel synthesis at neutral pH in W/O microemulsion: A method for enzyme nanoencapsulation in silica gel nanoparticles. Colloids and Surfaces A: Physicochemical and Engineering Aspects, 288(1-3), 52-61. 10.1016/j.colsurfa.2006.05.008

Clark, D. S. (1994). Can immobilization be exploited to modify enzyme activity? Trends in Biotechnology, 12(11), 439-443. 10.1016/0167-7799(94)90018-3

Claus, A., Carle, R., \& Schieber, A. (2008). Acrylamide in cereal products: A review. Journal of Cereal Science, 47(2), 118-133. 10.1016/j.jcs.2007.06.016

Covini, D., Tardito, S., Bussolati, O., R. Chiarelli, L., V. Pasquetto, M., Digilio, R. \& Scotti, C. (2011). Expanding Targets for a Metabolic Therapy of Cancer: L-Asparaginase. Recent Patents on Anti-Cancer Drug Discovery, 7(1), 4-13. 10.2174/157489212798358001

Cruz, M. E. M., Martins, M. B., Corvo, M. L., Gaspar, M. M., Oliveira, E. M. M., \& Ferrara, M. A. (2008). Enzimas em medicamentos e diagnósticos. In Bon, E. P. S.; Ferrara, M. A. \& Corvo, M. L. (Eds.), Enzimas em Biotecnologia: Produção, Aplicações e Mercado, (pp. 307-331). Interciência.

Desai, S. S., \& Hungund, B. S. (2018). Submerged fermentation, purification, and characterization of L-asparaginase from Streptomyces sp. isolated from soil Journal of Applied Biology \& Biotechnology, 6(5), 17-23. 10.7324/jabb.2018.60503

Dias, F. F. G., Bogusz Junior, S., Hantao, L. W., Augusto, F., \& Sato, H. H. (2017). Acrylamide mitigation in French fries using native L-asparaginase from Aspergillus oryzae CCT 3940. LWT - Food Science and Technology, 76, 222-229. https://doi.org/10.1016/j.1wt.2016.04.017

Dias, F. F. G., Ruiz, A. L. T. G., Torre, A. Della, \& Sato, H. H. (2016). Purification, characterization and antiproliferative activity of L-asparaginase from Aspergillus oryzae CCT 3940 with no glutaminase activity. Asian Pacific Journal of Tropical Biomedicine, 6(9), 785-794. 10.1016/j.apjtb.2016.07.007

El-Naggar, N. E. A., Deraz, S. F., Soliman, H. M., El-Deeb, N. M., \& El-Ewasy, S. M. (2016). Purification, characterization, cytotoxicity and anticancer activities of L-asparaginase, anti-colon cancer protein, from the newly isolated alkaliphilic Streptomyces fradiae NEAE-82. Scientific Reports, 6(August), 116. $10.1038 /$ srep 32926

El-Refai, H. A., Shafei, M. S., Mostafa, H., El-Refai, A. M. H., Araby, E. M., El-Beih, F. M. \& Easa, S. M. (2016). Comparison of free and immobilized Lasparaginase synthesized by gamma-irradiated Penicillium cyclopium. Polish Journal of Microbiology, 65(1), 43-50. 10.5604/17331331.1197274

El-Sharkawy, A. S., Farag, A. M., Embaby, A. M., Saeed, H., \& El-Shenawy, M. (2016). Cloning, expression and characterization of aeruginosa EGYII LAsparaginase from Pseudomonas aeruginosa strain EGYII DSM 101801 in E. coli BL21(DE3) pLysS. Journal of Molecular Catalysis B: Enzymatic, 132, 1623. doi: 10.1016/j.molcatb.2016.06.011

Elmore, S. J., Koutsidis, G., Dodson, A. T., Mottram, D. S., \& Wedzicha, B. L. (2005). Measurement of acrylamide and its precursors in potato, wheat, and rye model systems. Journal of Agricultural and Food Chemistry, 53(4), 1286-1293. 10.1021/jf048557b

Erdogan, A., Koytepe, S., Ates, B., Yilmaz, I., \& Seckin, T. (2014). Preparation of the L-asparaginase-based biosensor with polyimide membrane electrode for monitoring l-asparagine levels in leukemia. International Journal of Polymeric Materials and Polymeric Biomaterials, 63(17), 909-917. $10.1080 / 00914037.2014 .886228$

Feng, Y., Liu, S., Jiao, Y., Gao, H., Wang, M., Du, G., \& Chen, J. (2017). Enhanced extracellular production of L-asparaginase from Bacillus subtilis 168 by B. subtilis WB600 through a combined strategy. Applied Microbiology and Biotechnology, 101(4), 1509-1520. 10.1007/s00253-016-7816-X 
Research, Society and Development, v. 10, n. 10, e596101018980, 2021 (CC BY 4.0) | ISSN 2525-3409 | DOI: http://dx.doi.org/10.33448/rsd-v10i10.18980

Ghosh, S., Chaganti, S. R., \& Prakasham, R. S. (2012). Polyaniline nanofiber as a novel immobilization matrix for the anti-leukemia enzyme 1-asparaginase. Journal of Molecular Catalysis B: Enzymatic, 74(1-2), 132-137. 10.1016/j.molcatb.2011.09.009

Granvogl, M., \& Schieberle, P. (2006). Thermally generated 3-aminopropionamide as a transient intermediate in the formation of acrylamide. Journal of Agricultural and Food Chemistry, 54(16), 5933-5938. 10.1021/jf061150h

Gurung, N., Ray, S., Bose, S., Rai, V., \& K, W. F. (2013). A Broader View: Microbial Enzymes and Their Relevance in Industries , Medicine , and Beyond. BioMed Research International, Article 329121. https://doi.org/10.1155/2013/329121

Hendriksen, H. V., Kornbrust, B. A., Ostergaard, P. R., \& Stringer, M. A. (2009). Evaluating the potential for enzymatic acrylamide mitigation in a range of food products using an asparaginase from Aspergillus oryzae. Journal of Agricultural and Food Chemistry, 57(10), 4168-4176. 10.1021/jf900174q

Huang, L., Liu, Y., Sun, Y., Yan, Q., \& Jiang, Z. (2014). Biochemical characterization of a novel L-asparaginase with low glutaminase activity from Rhizomucor miehei and its application in food safety and leukemia treatment. Applied and Environmental Microbiology, 80(5), 1561-1569. 10.1128/AEM.03523-13

Husain, I., Sharma, A., Kumar, S., \& Malik, F. (2016). Purification and characterization of glutaminase free asparaginase from Enterobacter cloacae: In-vitro evaluation of cytotoxic potential against human myeloid leukemia HL-60 cells. PLoS ONE, 11(2), Article e0148877. 10.1371/journal.pone.0148877

Husain, I., Sharma, A., Kumar, S., \& Malik, F. (2016b). Purification and characterization of glutaminase free asparaginase from Pseudomonas otitidis: Induce apoptosis in human leukemia MOLT-4 cells. Biochimie, 121, 38-51. 10.1016/j.biochi.2015.11.012

IARC - International Agency for Research on Cancer (2014). Report of the advisory group to recommend priorities for IARC Monographs during 2015-2019. World Health Organization.

Izadpanah, F., Homaei, A., Fernandes, P., \& Javadpour, S. (2018). Marine microbial L-asparaginase: Biochemistry, molecular approaches and applications in tumor therapy and in food industry. Microbiological Research, 208, 99-112. 10.1016/j.micres.2018.01.011

Jaskólski, M., Kozak, M., Lubkowski, J., Palm, G., \& Wlodawer, A. (2001). Structures of two highly homologous bacterial L-asparaginases: A case of enantiomorphic space groups. Acta Crystallographica Section D: Biological Crystallography, 57(3), 369-377. 10.1107/S0907444900020175

Jiao, L., Chi, H., Lu, Z., Zhang, C., Chia, S. R., Show, P. L. \& Tao, Y., et al. (2020). Characterization of a novel type I L-asparaginase from Acinetobacter soli and its ability to inhibit acrylamide formation in potato chips. Journal of Bioscience and Bioengineering, 129(6), 672-678. 10.1016/j.jbiosc.2020.01.007

Jin, C., Wu, X., \& Zhang, Y. Relationship between antioxidants and acrylamide formation: A review. Food Research International, 51, 611-620. 10.1016/j.foodres.2012.12.047

Karamitros, C. S., Yashchenok, A. M., Möhwald, H., Skirtach, A. G., \& Konrad, M. (2013). Preserving catalytic activity and enhancing biochemical stability of the therapeutic enzyme asparaginase by biocompatible multilayered polyelectrolyte microcapsules. Biomacromolecules, 14(12), 4398-4406. $10.1021 / \mathrm{bm} 401341 \mathrm{k}$

Kidd, J. G. (1953). Regression of transplanted lymphomas induced in vivo by means of normal guinea pig serum. I. Course of transplanted cancers of various kinds in mice and rats given guinea pig serum, horse serum, or rabbit serum. The Journal of experimental medicine, 98(6), 565-582. 10.1084/jem.98.6.565

Kotzia, G. A., \& Labrou, N. E. (2007). 1-Asparaginase from Erwinia chrysanthemi 3937: Cloning, expression and characterization. Journal of Biotechnology, 127(4), 657-669. 10.1016/j.jbiotec.2006.07.037

Krishnapura, P. R., \& Belur, P. D. (2016). Partial purification and characterization of L-asparaginase from an endophytic Talaromyces pinophilus isolated from the rhizomes of Curcuma amada. Journal of Molecular Catalysis B: Enzymatic, 124, 83-91. 10.1016/j.molcatb.2015.12.007

Krishnapura, P. R., Belur, P. D., \& Subramanya, S. (2016). A critical review on properties and applications of microbial 1-asparaginases. Critical Reviews in Microbiology, 42(5), 720-737. 10.3109/1040841X.2015.1022505

Kumar, K., \& Verma, N. (2012). The Various Sources \& Application of L-Asparaginase. Asian Journal of Biochemical and Pharmaceutical Research, 2(3), 197-205.

Kunamneni, A., Ogaugwu, C., \& Goli, D. (2018). Enzymes as therapeutic agents. In Nunes, C. S., \& Kumar, V. (Eds.), Enzymes in Human and Animal Nutrition: Principles and Perspectives (pp. 301-312). https://doi.org/10.1016/B978-0-12-805419-2.00015-0

Labrou, N. E., \& Muharram, M. M. (2016). Biochemical characterization and immobilization of Erwinia carotovora L-asparaginase in a microplate for highthroughput biosensing of L-asparagine. Enzyme and Microbial Technology, 92, 86-93. 10.1016/j.enzmictec.2016.06.013

Li, S., Yang, X., Yang, S., Zhu, M., \& Wang, X. (2012). Technology prospecting on enzymes: Application, marketing and engineering. Computational and Structural Biotechnology Journal, 2(3), Article e201209017. 10.5936/csbj.201209017

Lincoln, L., Niyonzima, F., \& More, S. (2019). Purification and Properties of a Fungal L-Asparaginase from Trichoderma viride Pers: Sf Grey. Journal of Microbiology, Biotechnology and Food Sciences, 9(6), 310-316.

Liu, J. (2018). Acrylamide is formed in the Maillard reaction. Journal of the science of food and agriculture, 98(1), 448-449. 10.1007/s11947-010-0495-1

Ln, R., Doble, M., Rekha, V. P. B., \& Pulicherla, K. K. (2011). In silico engineering of L-asparaginase to have reduced glutaminase side activity for effective treatment of acute lymphoblastic leukemia. Journal of Pediatric Hematology/Oncology, 33(8), 617-621. 10.1097/MPH.0b013e31822aa4ec

Mashburn, L. T., \& Wriston, J. C. (1963). Tumor inhibitory effect of L-asparaginase. Biochemical and Biophysical Research Communications, 12(1), 50-55. 
Research, Society and Development, v. 10, n. 10, e596101018980, 2021 (CC BY 4.0) | ISSN 2525-3409 | DOI: http://dx.doi.org/10.33448/rsd-v10i10.18980

$10.1016 / 0003-9861(64) 90032-3$

Mateo, C., Palomo, J. M., \& Fernández-Lorente, G. (2007). Improvement of enzyme activity, stability and selectivity via immobilization techniques. Enzyme and Microbial Technology, 40, 1451-1463. 10.1016/j.enzmictec.2007.01.018

Meena, B., Anburajan, L., Dheenan, P. S., Begum, M., Vinithkumar, N. V., Dharani, G., \& Kirubagaran, R. (2015). Novel glutaminase free 1-asparaginase from Nocardiopsis alba NIOT-VKMA08: Production, optimization, functional and molecular characterization. Bioprocess and Biosystems Engineering, 38(2), 373-388. 10.1007/s00449-014-1277-3

Meghavarnam, A. K., \& Janakiraman, S. (2018). Evaluation of acrylamide reduction potential of L-asparaginase from Fusarium culmorum (ASP-87) in starchy products. LWT - Food Science and Technology, 89, 32-37. 10.1016/j.lwt.2017.09.048

Mesias, M., Delgado-Andrade, C., Holgado, F., \& Morales, F. J. (2018). Acrylamide content in French fries prepared in households: A pilot study in Spanish homes. Food Chemistry, 260, 44-52. 10.1016/j.foodchem.2018.03.140

Mesias, M., \& Morales, F. J. (2016). Acrylamide in coffee: Estimation of exposure from vending machines. Journal of Food Composition and Analysis, 48, 812. $10.1016 /$ j.jfca.2016.02.005

Mohan Kumar, N. S., \& Manonmani, H. K. (2013). Purification, characterization and kinetic properties of extracellular 1-asparaginase produced by Cladosporium sp. World Journal of Microbiology and Biotechnology, 29(4), 577-587. 10.1007/s11274-012-1213-0

Mohan Kumar, N. S., Shimray, C. A., Indrani, D., \& Manonmani, H. K. (2014). Reduction of Acrylamide Formation in Sweet Bread with 1-Asparaginase Treatment. Food and Bioprocess Technology, 7(3), 741-748. 10.1007/s11947-013-1108-6

Moher, D., Liberati, A., Tetzlaff, J., \& Altman, D. G. (2014). PRISMA 2009 Flow Diagram Identification. Annals of Internal Medicine, 151(2), 264-269.

Mottram, D. S., Wedzicha, B. L., \& Dodson, A. T. (2002). Food chemistry: Acrylamide is formed in the Maillard reaction. Nature, 419(6906), 448-449. $10.1038 / 419448 \mathrm{a}$

Mu, X., Qiao, J., Qi, L., Dong, P., \& Ma, H. (2014). Poly(2-vinyl-4,4-dimethylazlactone)-functionalized magnetic nanoparticles as carriers for enzyme immobilization and its application. ACS Applied Materials and Interfaces, 6(23), 21346-21354. 10.1021/am5063025

Muslim, S. N., Kadmy, I. M. S. A. L., \& Hussein, N. H. (2015). Enhancement of the Activity and Stability of L-Asparaginase Food Additive Purified from Acinetobacter baumannii as Anticarcinogenic in Processed Foods. International Journal of Advances in Chemical Engineering and Biological Sciences, 2(1). https://doi.org/10.15242/ijacebs.c0815019

Mustafa, A., Kamal-Eldin, A., Petersson, E. V., Andersson, R., \& Åman, P. (2008). Effect of extraction pH on acrylamide content in fresh and stored rye crisp bread. Journal of Food Composition and Analysis, 21(4), 351-355. 10.1016/j.jfca.2008.01.003

Narta, U. K., Kanwar, S. S., \& Azmi, W. (2007). Pharmacological and clinical evaluation of 1-asparaginase in the treatment of leukemia. Critical Reviews in Oncology/Hematology, 61(3), 208-221. 10.1016/j.critrevonc.2006.07.009

Onishi, Y., Prihanto, A. A., Yano, S., Takagi, K., Umekawa, M., \& Wakayama, M. (2015). Effective treatment for suppression of acrylamide formation in fried potato chips using L-asparaginase from Bacillus subtilis. 3 Biotech, 5(5), 783-789. 10.1007/s13205-015-0278-5

Orhan, H., \& Aktaş Uygun, D. (2020). Immobilization of L-Asparaginase on Magnetic Nanoparticles for Cancer Treatment. Applied Biochemistry and Biotechnology, 191(4), 1432-1443. 10.1007/s12010-020-03276-z

Outcome of the public consultation on the draft Scientific Opinion of the EFSA Panel on Contaminants in the Food Chain (CONTAM) on acrylamide in food. (2017) EFSA Supporting Publications, 12(6). https://doi.org/10.2903/sp.efsa.2015.en-817

Panel, E., \& Chain, F. (2015). Scientific Opinion on acrylamide in food. EFSA Journal, 13(6). 10.2903/j.efsa.2015.4104

Parker, J. K., Balagiannis, D. P., Higley, J., Smith, G., Wedzicha, B. L., \& Mottram, D. S. (2012). Kinetic model for the formation of acrylamide during the finish-frying of commercial French fries. Journal of Agricultural and Food Chemistry, 60(36), 9321-9331. 10.1021/jf302415n

Pedreschi, F., Kaack, K., \& Granby, K. (2008). The effect of asparaginase on acrylamide formation in French fries. Food Chemistry, 109(2), 386-392. 10.1016/j.foodchem.2007.12.057

Pedreschi, F., Mariotti, S., Granby, K., \& Risum, J. (2011). Acrylamide reduction in potato chips by using commercial asparaginase in combination with conventional blanching. LWT - Food Science and Technology, 44(6), 1473-1476. 10.1016/j.lwt.2011.02.004

Pieters, R., Hunger, S. P., Boos, J., Rizzari, C., Silverman, L., Baruchel, A. \& Goekbuget, N., et al. (2011). L-asparaginase treatment in acute lymphoblastic leukemia. Cancer, 117(2), 238-249. 10.1002/cncr.25489

Pourhossein, M., \& Korbekandi, H. (2014). Cloning, expression, purification and characterisation of Erwinia carotovora L-asparaginase in Escherichia coli. Advanced Biomedical Research, 3(1), 82. 10.4103/2277-9175.127995

Ramya, L. N., Doble, M., Rekha, V. P. B., \& Pulicherla, K. K. (2012). L-asparaginase as potent anti-leukemic agent and its significance of having reduced glutaminase side activity for better treatment of acute lymphoblastic leukemia. Applied Biochemistry and Biotechnology, 167, 2144-2159. 10.1007/s12010012-9755-z

Ravi, A., \& Gurunathan, B. (2018). Acrylamide mitigation in fried kochchi kesel chips using free and immobilized fungal asparaginase. Food Technology and Biotechnology, 56(1), 51-57. 10.17113/ftb.56.01.18.5422 
Research, Society and Development, v. 10, n. 10, e596101018980, 2021

(CC BY 4.0) | ISSN 2525-3409 | DOI: http://dx.doi.org/10.33448/rsd-v10i10.18980

Rigon Zimmer, K., Luís Borré, G., da Silva Trentin, D., Woicickoski Júnior, C., Piccoli Frasson, A., de Arruda Graeff, A. \& Gomes, P., et al. (2009). Enzimas microbianas de uso terapêutico e diagnóstico clínico. Revista Liberato, 10(14), 123-137. 10.31514/rliberato.2009v10n14.p123

Rocha Junior, C., \& Caseli, L. (2017). Adsorption and enzyme activity of asparaginase at lipid Langmuir and Langmuir-Blodgett films. Materials Science and Engineering C, 73, 579-584. 10.1016/j.msec.2016.12.041

Sanghvi, G., Bhimani, K., Vaishnav, D., Oza, T., Dave, G., Kunjadia, P., \& Sheth, N. (2016). Mitigation of acrylamide by 1-asparaginase from Bacillus subtilis KDPS1 and analysis of degradation products by HPLC and HPTLC. SpringerPlus, 5(1), Article 533. https://doi.org/10.1186/s40064-016-2159-8

Sanny, M., Luning, P. A., Jinap, S., Bakker, E. J., \& Van Boekel, M. A. J. S. (2013). Effect of frying instructions for food handlers on acrylamide concentration in French fries: An explorative study. Journal of Food Protection, 76(3), 462-472.

Şenyuva, H. Z., \& Gökmen, V. (2005). Study of acrylamide in coffee using an improved liquid chromatography mass spectrometry method: Investigation of colour changes and acrylamide formation in coffee during roasting. Food Additives and Contaminants, 22(3), 214-220. 10.1080/02652030500109834

Shakambari, G., Birendranarayan, A. K., Angelaa Lincy, M. J., Rai, S. K., Ahamed, Q. T., Ashokkumar, B. \& Saravanan, M., et al. (2016). Hemocompatible glutaminase free 1-asparaginase from marine Bacillus tequilensis PV9W with anticancer potential modulating p53 expression. RSC Advances, 6(31), 2594325951. 10.1039/c6ra00727a

Shi, R., Liu, Y., Mu, Q., Jiang, Z., \& Yang, S. (2017). Biochemical characterization of a novel L-asparaginase from Paenibacillus barengoltzii being suitable for acrylamide reduction in potato chips and mooncakes. International Journal of Biological Macromolecules, 96, 93-99. 10.1016/j.ijbiomac.2016.11.115

Singh, M., Hassan, N., Verma, D., Thakur, P., Panda, B. P., Panda, A. K., Sharma, R. K., Mirza, A., Mansoor, S., Alrokayan, S. H., Khan, H. A., Ahmad, P., \& Iqbal, Z. (2020). Design of expert guided investigation of native L-asparaginase encapsulated long-acting cross-linker-free poly (lactic-co-glycolic) acid nanoformulation in an Ehrlich ascites tumor model. Saudi Pharmaceutical Journal, 28(6), 719-728. 10.1016/j.jsps.2020.04.014

Souza, P. M., de Freitas, M. M., Cardoso, S. L., Pessoa, A., Guerra, E. N. S., \& Magalhães, P. O. (2017). Optimization and purification of L-asparaginase from fungi: A systematic review. Critical Reviews in Oncology/Hematology, 120, 194-202. 10.1016/j.critrevonc.2017.11.006

Sukhoverkov, K. V., \& Kudryashova, E. V. (2015). PEG-chitosan and glycol-chitosan for improvement of biopharmaceutical properties of recombinant Lasparaginase from Erwinia carotovora. Biochemistry, 80(1), 113-119. 10.1134/S0006297915010137

Tyl, R. W., \& Friedman, M. A. (2003). Effects of acrylamide on rodent reproductive performance. Reproductive Toxicology, 17(1), 1-13. 10.1016/S0890$6238(02) 00078-3$

Ulu, A. (2020). Metal-organic frameworks (MOFs): a novel support platform for ASNase immobilization. Journal of Materials Science, 55(14), 6130-6144. $10.1007 / \mathrm{s} 10853-020-04452-6$

Ulu, A., Koytepe, S., \& Ates, B. (2016). Synthesis and characterization of biodegradable pHEMA-starch composites for immobilization of L-asparaginase. Polymer Bulletin, 73(7), 1891-1907. 10.1007/s00289-015-1583-1

Vala, A. K., Sachaniya, B., Dudhagara, D., Panseriya, H. Z., Gosai, H., Rawal, R., \& Dave, B. P. (2018). Characterization of L-asparaginase from marinederived Aspergillus niger AKV-MKBU, its antiproliferative activity and bench scale production using industrial waste. International Journal of Biological Macromolecules, 108, 41-46. 10.1016/j.ijbiomac.2017.11.114

Van Den Berg, H. (2011). Asparaginase revisited. Leukemia and Lymphoma, 52 (2), 168-178. 10.3109/10428194.2010.537796

Varma, R., Kanapala, S., V, N. S. B., Bodaiah, B., \& Poda, S. (2016). Partial purification , characterization and optimization of anti-leukemic enzyme LAsparaginase from mangrove soil Actinobacteria. Journal of Pharmacy Research, 10(7), 502-511.

Verma, N., Kumar, K., Kaur, G., \& Anand, S. (2007). L-asparaginase: A promising chemotherapeutic agent. Critical Reviews in Biotechnology, 27(1), 45-62. $10.1080 / 07388550601173926$

Xu, F., Oruna-Concha, M. J., \& Elmore, J. S. (2016). The use of asparaginase to reduce acrylamide levels in cooked food. Food Chemistry, 210, 163-171. 10.1016/j.foodchem.2016.04.105

Zamora, R., \& Hidalgo, F. J. (2008). Contribution of lipid oxidation products to acrylamide formation in model systems. Journal of Agricultural and Food Chemistry, 56, 6075-6080. 10.1021/jf073047d

Zhang, Y. Q., Tao, M. L., Shen, W. De, Zhou, Y. Z., Ding, Y., Ma, Y., \& Zhou, W. L. (2004). Immobilization of L-asparaginase on the microparticles of the natural silk sericin protein and its characters. Biomaterials, 25(17), 3751-3759. 10.1016/j.biomaterials.2003.10.019

Zuo, S., Zhang, T., Jiang, B., \& Mu, W. (2015). Reduction of acrylamide level through blanching with treatment by an extremely thermostable 1-asparaginase during French fries processing. Extremophiles, 19(4), 841-851. 10.1007/s00792-015-0763-0 